\title{
Resistance of Human Skin to Puncture and Laceration
}

Bernard J. McGuire

John R. Sorrells

John D. Moore

Performance Criteria Section

Product Systems Section

Product Evaluation Technology Division

February 10,1973

Report to

Bureau of Product Safety

Food and Drug Administration

Department of Health, Education, and Welfare 



\section{RESISTANCE OF HUMAN SKIN TO PUNCTURE AND LACERATION}

Bernard J. McGuire John R. Sorrells

John D. Moore

Performance Criteria Section

Product Systems Section

Product Evaluation Technology Division

February 10,1973

This is a progress report. The work is incomplete and is continuing. Conclusions are not necessarily those that will be included in a final report

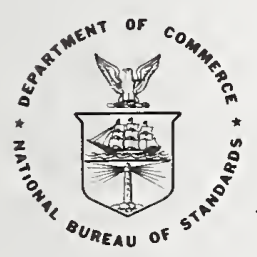

U. S. DEPARTMENT OF COMMERCE, Frederick B. Dent, Secretary 



\section{INTRODUCTION}

In support of the Bureau of Product Safety's program to improve toy safety, the NBS Product Evaluation Technology Division has been studying the problem of determining the degree of hazard associated with the use of toys having points and edges of various degrees of sharpness. The final goal of this project is to develop a definition of and a simple test method or device that will differentiate between "hazardous" and "non-hazardous" toy configurations. In order to do this, however, the investigation must cover many areas of interest. The first report on this project, NBS Report No. 10,673 by Moore (1972), provided results of preliminary subjective evaluations of point sharpness and described the construction of a mechanical device for easily measuring point sharpness and strength. The second report, NBS No. 10,839 by McGuire and Moore (1972), provided further definition of the skin puncture problem, including a review of published data, and gave results of subjective evaluations of point sharpness by physicians, results of laboratory tests on the puncture resistance of pigskin, preliminary results of tests on the puncture resistance of human skin, and an evaluation of the injury potential of various points. The present report, third in the series, provides further discussion of the general problem area, additional data on the physical properties of human skin and gives results of tests to measure hand-toy impact velocities and the cutting effects of sheared steel edges on 
pigskin at appropriate impact velocities. Some preliminary information on the puncture resistance of pigskin under dynamic conditions is also given. 


\section{CONCLUSIONS}

1. Human skin tensile strength and modulus of elasticity increase rapidly during the first year of life and reach near adult values by age one year. (See section I A and Figures 1 and 2.)

2. The resistance of adult human skin to puncture by Moore penetrometer tips can be described by equations of the form $y=u+a x_{1}+b x_{2}+c^{2} x_{1}^{2}+d x_{2}^{2}$. (See Section $I B$ and Figure 8).

3. The estimated average puncture force curve previously provided by McGuire and Moore (1972) can still be considered a reasonable dividing line between hazardous and non-hazardous points under essentially static conditions. (See Section I B.) Work now in progress may define other criteria for points hazardous under dynamic conditions. (See Conclusion No. 8.)

4. Hand velocities achieved by children of age 5 to 8 years are approximately 2.1 to 2.5 meters/sec. for "quick-grab" motions, and approximately 6.4 to 7.3 meters/sec. for "karate chop" motions, based on a small sample. (See Section II A.)

5. The "effective weights" of children's hands and forearms for ages 5 to 8 years are approximately 0.3 to $0.6 \mathrm{~kg}$, based on a small sample. (See Section II A.)

6. The pendulum skin test device used in this study provided a useful first approximation of some possible hand-toy 
impact conditions, but the device is not considered suitable for use in further testing. (See sections II B, III A, III C, and Figures 9, 10, and 11.)

7. For a wide range of quality of sheared steel edges, all such edges cut pigskin under impact conditions that are easily achieved by the hands of children age 8 years. Probably the sheared edges would cut human skin under the same conditions. (See Section III D and Figure 12.)

8. Based on preliminary information obtained with a new dynamic skin test device, even the least hazardous of the present set of Moore penetrometer tips punctures pigskin under impact conditions that are easily achieved by the hands of children age 8 years. Probably the tips would also puncture human skin under the same conditions. (See Section IV B.) 


\section{DISCUSSION}

This technical progress report describes new information obtained since the publication of NBS Report No. 10,839 dated April 27, 1972. It covers material from several areas of interest but is not intended to be an all-inclusive or final report.

Discussion is divided into the following topics:

I. Mechanical Properties of Human Skin
A. Tensile Properties
B. Static Puncture Resistance

II. Pendulum Skin Test Device Development
A. Hand Velocity and Weight Measurements
B. Pendulum Design

III. Cutting Tests of Pigskin with Sheared Steel Edges
A. Test Edges
B. Test Tissue
C. Test Method
D. Test Results

IV. Continuing Activities
A. Improved Test Methods
B. Dynamic Skin Puncture Test Results (Preliminary)
C. Easy-Open Food Containers
D. Basic Skin Properties

V. References 


\section{MECHANICAL PROPERTIES OF HUMAN SKIN}

A. Tensile Propexties

Among the technical papers discussed by McGuire and Moore (1972) was one by Holzmann, Korting, Kobert, and Vogel (1971) that described the thickness, breaking force for $5 \mathrm{~mm}$ width, percent elongation, and modulus of elasticity of skin from the thigh and over the sternum of 52 unembalmed cadavers of various ages. These data, as published, were grouped into age categories. In response to an NBS request, co-author H. G. VogeI furnished detailed information on each skin specimen tested during the study described in that paper.

Of the data furnished by Vogel (1972), those from the 14 youngest cadavers are represented in Figures 1 and 2. They indicate that the force required to break a $5 \mathrm{~mm}$ wide skin specimen roughly doubles during the İist year of life. After the first year, change is more gradual.

McGuire and Moore (1972) had postulated that skin puncture force bore a certain relationship (Figure 32 of that report) to skin breaking strength. Also, it was shown that average skin breaking force for children in the 0-10 year age group was approximately equal to skin breaking force for persons in the 60-70 
year age group for many parts of the body. It was, therefore, concluded that the skin puncture data obtained from older cadavers were approximately equal to those that would have been obtained from younger cadavers. On the basis of the data provided by Vogel (1972), it still appears that this might hold true, but only down to about one year of age.

B. Static Puncture Resistance

McGuire and Moore (1972) presented preliminary results from a study of human skin resistance to puncture under low velocity, or essentially static, conditions. In the study, the puncture resistance of skin from five locations on 21 unembalmed cadavers was measured using the nine different penetrometer tips. This work, which was performed by W. H. Graham of the Office of the Chief Medical Examiner of the State of Virginia, is now complete.

The five skin test locations used in this study were selected primarily on the basis of their vulnerability to injury and the fact that average skin strength was expected to be measurably different in each location. In one location, the neck, measurements were also made of the puncture resistance of the skin backed up by the platysma, which is a thin sheet of muscle which forms a part of the subcutaneous 
tissue in that area. The cadavers used, described in Figure 4, were simply those that became available for research use during the study, and were not specially selected. The penetrometer tips used, shown in Figure 3, were selected because previous work had indicated that they would best help define the puncture force regions of greatest interest in the study.

To measure the skin puncture force, an incision was made in the cadaver skin at the desired location and a lead-surfaced spatula blade was inserted under the skin. The appropriate penetrometer tip was mounted in a hand-held force measuring device. The penetrometer tip was pressed perpendicularly through the skin until it made contact with the lead surface, completing an electrical circuit and causing a small light bulb to go on. At this signal the operator read the force-indicating dial on the force-measuring device. The lead-surfaced spatula blade was intended to simulate the effect of human bone just beneath the skin. This test condition was chosen because previous tests reported by McGuire and Moore (1972) had indicated that skin was more vulnerable to puncture when backed by a rigid surface than when backed by resilient muscle or other soft tissue. Therefore, the test condition represented a "worse case" condition from the standpoint of skin puncture. A lead surface was used rather than bone 
so that the electrical signal could be used to indicate complete puncture. The test equipment and method are more fully explained by McGuire and Moore (1972). The puncture force data obtained are shown in Figures 5 and 6. Except for the measurements made on the neck skin with platysma, the data were analyzed statistically by the NBS Applied Mathematics Division using the NBS-developed OMNITAB II computing system described by Hogben, et al (1971). (OMNITAB II is available outside NBS; see Hogben, et al 1970.) The following two paragraphs may be of particular interest to those versed in statistical theory.

An analysis of variance was made, treating the experiment as a two-way nested design without replications. That is, "penetrometer tips" and "bodies" were treated as independent variables with "body locations" nested within "bodies." Since there were no replications, there was no direct measure of experimental error as such. In the absence of a direct measure of experimental error, the tips $\mathrm{x}$ locations within bodies mean square, 1.83, could be used as an estimate of error variance with 672 degrees of freedom. This would only be valid if, in fact, there were no interaction. This is not a realistic assumption.

Results of the analysis are shown in conventional form in Figure 7. Measured differences between tips, 
between bodies, and between locations within bodies were all found to be significant at the .01 significance level. This indicated that the measured differences were primarily due to purposeful changes in test conditions rather than random variations in materials or methods. For each of the five body locations, data obtained from the 21 cadavers using the 8 Moore penetrometer tips were examined and found to describe series of constant-force curves approximating sections of ellipses. Therefore, computations were made to determine the values for constants that would provide least-squares fits between the puncture force data and the following general equation for an ellipse:

$$
y=u+a x_{1}+b x_{2}+c x_{1}^{2}+d x_{2}^{2}
$$

where

$$
\begin{array}{ll}
\mathrm{y} & =\text { puncture force, } \mathrm{kg} \\
\mathrm{x}_{1}=\text { tip angle, degrees (see Figure 3) } \\
\mathrm{x}_{2}=\text { tip radius, } \mathrm{mm} & \text { and }
\end{array}
$$

\begin{tabular}{|c|c|c|c|c|c|}
\hline \multirow{2}{*}{$\begin{array}{c}\text { Body } \\
\text { Location }\end{array}$} & \multicolumn{2}{|c|}{ Least } & Esti & \multicolumn{2}{|c|}{ of Constants } \\
\hline & u & $a$ & $b$ & $c$ & d \\
\hline Forehead & 1.5731 & .04417 & -1.9811 & .000447 & 18.7539 \\
\hline Cheek & 1.8688 & .00952 & -0.4453 & .000826 & 13.9832 \\
\hline Scalp & 1.9421 & .02448 & -0.7072 & .000851 & 18.2296 \\
\hline Forearm & 1.8669 & .00749 & -0.9636 & .000872 & 21.2810 \\
\hline Neck & 1.2223 & -.00712 & +1.6636 & .001326 & 22.3977 \\
\hline
\end{tabular}

$$
u, a, b, c, d=\text { constants }
$$

Results of these computations were as follows: 
These values were then used in the general equation to compute sets of values for $x_{1}$ and $x_{2}$ for the condition where puncture force $y=7.5 \mathrm{~kg}$. The resulting curves are shown in Figure 8. A curve previously estimated by McGuire and Moore (1972) is also shown in this figure. The $7.5 \mathrm{~kg}$ force level selected was based on children's grip strength, and will be discussed later in this section.

Since each of the five curves shown in Figure 8 represents all the measurements made at one body location on 21 cadavers by 8 Moore penetrometer tips, each curve might be considered to be an "average" $7.5 \mathrm{~kg}$ puncture force curve for a given body location. However, the range of puncture force values obtained with any one penetrometer tip at a given body location varied widely, as shown in Figures 5 and 6. This variation was due to the combined effect of natural differences between cadavers and experimental error in measuring puncture forces. Of these two factors, natural differences between cadavers probably produced the greatest variation. The fact that no measurements were repeated, however, prevents calculation of the proportion of the total variation attributable to each cause. 
Computations were made to determine the $95 \%$ confidence interval for measurements made at any one body location by any one Moore penetrometer tip, considering variation due to the combined effects of body differences and measurement errors. As an example, as shown in Figure 5 the mean value for all puncture force measurements made with the 60 degree, $.4 \mathrm{Imm}$ Moore tip on the foreheads of the 21 cadavers was $8.1 \mathrm{~kg}$. A $95 \%$ confidence interval for a single measurement is $8.1 \pm 3.9 \mathrm{~kg}$ based on 16 degrees of freedom. In general, the confidence limits were nearly identical for all tips at each body location, but quite different between body locations. The calculated values for $95 \%$ confidence limits, rounded to the nearest $0.1 \mathrm{~kg}$, were as follows (mean values indicated refer to those shown in Figures 5 and 6 for each tip):

Forehead mean value for individual tip $+3.9 \mathrm{~kg}$ (range of means 3.5 to $8.1 \mathrm{~kg}$ )

Cheek mean value for individual tip $\pm 3.1 \mathrm{~kg}$ (range of means 3.3 to $7.5 \mathrm{~kg}$ )

Scalp mean value for individual tip $\pm 5.7 \mathrm{~kg}$ (range of means 4.0 to $9.4 \mathrm{~kg}$ )

Forearm mean value for individual tip $+3.9 \mathrm{~kg}$ (range of means 3.9 to $9.4 \mathrm{~kg}$ )

Neck

mean value for individual tip $\pm 4.0 \mathrm{~kg}$ (range of means 4.0 to $10.7 \mathrm{~kg}$ ) 
The calculated confidence intervals are very large, but this is not unusual for data representing measurements of biological attributes. The fact remains that the curves in Figure 8 are still reasonable estimates of the puncture resistance of human skin.

The $7.5 \mathrm{~kg}$ force level used in the curves in Figure 8 was based on the grip strength of children 5 years of age as described by Krogman and McCown (1971). If grip strength is a valid criteria, it is not unreasonable to think that children of less than 1 year of age would be able to exert much less force on an object and the fact that their skin is weaker would be at least partly balanced by their lesser strength. However, we do not now have enough data to adequately define this trade-off.

It should be noted that although the puncture force work to date has dealt with essentially static conditions, future work may indicate that dynamic conditions are of greater importance. With the present data serving as a foundation, work is now being done to determine the effects of dynamic interactions between body parts and sharp points and edges. As discussed in greater detail in section IV B, early indications are that points that will not puncture human skin at the $7.5 \mathrm{~kg}$ static force level will puncture skin under dynamic conditions that can easily be 
achieved by children's hands. It is not yet known whether this is simply due to the greater forces involved or whether other dynamic effects are also significant. 
II. PENDULUM SKIN TEST DEVICE DEVELOPMENT

A. Hand Velocity and Weight Measurements

This phase of the toy safety program is primarily concerned with hazards encountered during ordinary play conditions as opposed to either essentially static conditions or very high energy situations. Therefore, the dynamic problems associated with hand-toy impact comprise one appropriate area for analysis.

Many of the factors affecting the degree of hand injury caused by a hand-toy impact can be discussed from an engineering viewpoint. For example, toy characteristics such as configuration, mass, and rigidity must be considered significant, with toys having sharp points or edges, high mass and high rigidity tending to produce the greatest injury in a given impact situation. Likewise, the mass, velocity, and resilience of the hand must be considered significant factors. However, the dynamic characteristics of the hand are particularly difficult to measure. One problem is that the supporting tissue under the skin varies greatly. On. the knuckles, where there is little soft subcutaneous tissue, a given impact velocity will tend to produce high decelerations and high impact forces. Areas having a substantial amount of soft tissue under the skin will tend to produce lower decelerations and lower impact forces. 
In order to make a first attempt at simulating some hand-toy impact conditions, a search was made for information on typical hand travel velocities and masses. Hand and forearm velocities (up to 4.4 meters/second during controlled movement) and weights are described by Damon, Stoudt, and McFarland (1966), but their data are all for adults. No published data on children were found, so measurements were made by the Product Evaluation Technology Division to determine typical values for children's hand velocities. Two miniature photo diodes mounted one inch apart were used to measure the hand velocities achieved by five subjects of various ages under two conditions. Maximum velocity measured was obtained by a downward "karate chop" motion past the photo diodes. Maximum grabbing velocity was measured during a quick horizontal grabbing motion from a standing start toward an object about $45 \mathrm{~cm}$ from the starting position. The effective weights of the subjects' hands were then measured. This was done by placing their arms in the position where the elbow joint supported the upper (proximal) end of the forearm, and the hand was supported by a scale. Thus, the weight measured was equal to the hand weight, plus approximately one-half of the forearm weight. 
Hand velocities and effective weights measured were:

\begin{tabular}{|c|c|c|c|}
\hline $\begin{array}{l}\text { Subject } \\
\text { Age } \\
\text { Years } \\
\end{array}$ & $\begin{array}{c}\text { Karate Chop } \\
\text { Velocity } \\
\text { Meters/sec. }\end{array}$ & $\begin{array}{l}\text { Quick Grab } \\
\text { Velocity } \\
\text { meters/sec. }\end{array}$ & $\begin{array}{c}\text { Effective } \\
\text { Weight } \\
\mathrm{kg}\end{array}$ \\
\hline 2 & 4.2 & - & $.2\langle e$ \\
\hline 5 & 6.4 & 2.1 & .3 \\
\hline 8 & 7.3 & 2.5 & .6 \\
\hline Adult (2) & 12.7 & 4.2 & 2.0 \\
\hline
\end{tabular}

B. Pendulum Design

A test device was built that was intended for use in simulating a variety of child-toy impact conditions. This device, shown in Figure 9, featured a light-weight pendulum arm long enough to produce impact velocities of up to the value of the maximum "quick-grab" velocities measured and a pivoted carrier to which various sharp edges or points could be attached. The pendulum head could be weighted to simulate the weight of a hand or other body part. The device was built with the tissue test specimen held stationary and the test edge movable so that it could be used for tests on human skin without the necessity of removing tissue specimens from the cadavers. However, this was never done.

The tissue test specimen shown in Figure 9 is chamois skin. Wet chamois skin was used in development 
of the test device, and some tests were later made using Eresh pigskin.

The pendulum test device provided a useful first approximation of some possible hand-toy impact conditions and was used for the series of tests described in Section III of this report. However, the interactions between the pendulum components and the test tissue were extremely complex. For example, higher pendulum release heights produced both higher cutting velocities and higher impact forces. It seemed unlikely that the relative effect of velocity and force, for example, could be determined without complex instrumentation. Also, successful use of the device depended on careful setting of edge impact angles and points of impact. Therefore, the device has been abandoned, and a "Eree-fall" drop test device is now being developed. The new device is further discussed in Section IV.

A satisfactory method for describing edge characteristics has not yet been found, though several ideas are being considered. Probably the most promising is a technique that would utilize a profilometer of the type ordinarily used to measure surface roughness. In place of the usual pointed stylus, a chisel-shaped stylus that could be passed over any edge would be 
used. Edge roughness might be expressed in terms of root mean square deviation from a given line, or by other appropriate terminology. 
III. CUTTING TESTS OF PIGSKIN WITH SHEARED STEEL EDGES

A. Test Edges

One of the specific problems facing the Bureau of Product Safety is determination of the hazard potential of toys made in whole or in part from thin steel components having unprotected sheared edges. BPS furnished a number of toys, including cars, mechanical animals, a xylophone, and a toy umbrella with sheared and formed steel ribs and handle, as examples of this problem. Sheared sheet steel edges were chosen as the most appropriate starting point for the edge evaluation work.

A set of sixteen sheared sheet steel edges was made in the general form shown in Figure 10. Characteristics of the edges were as described in Figure 12. Note the following variations:

1. The edges were made of $\underline{0.4}, \underline{0.6}$, and $\underline{1.5 \mathrm{~mm}}$ thickness steel.

2. Half of the edges were "O degree" and half were "37 degree" as defined in Figure 10.

3. Six of the edges were sheared on a "rough," very poor shear. Eight of the edges were sheared on a "good," well-maintained shear. Two of the edges were sheared on an "excellent" shear, which was actually just a relatively unused portion of the 
"good" shear. The better conditions of the shear produced the smaller wire edges on the sheared material.

4. After shearing, ten edges were left as sheared. Two edges were given 10 strokes on a fine stone, which removed the sharpest or "toothiest" part of their wire edges. Four edges were given 20 strokes on a fine stone, which removed their wire edges entirely and left smooth edges.

Neglecting for the moment the variables of edge angle and steel thickness, the various combinations of operations described above produced the four subjectively distinct types of edges illustrated in Figure 13. These are:

Type A. Smooth square edge. Feels sharp but smooth to touch. The best possible shear might approach, but would probably not attain, an edge of this smoothness. Test edges 8, 12, 14,16 .

Type B. Rough fine wire edge. Feels rough to touch. Typical manufacturing quality, similar to edges on most toys. Test edges 1, 2, 7, 11 . Of slightly better finish are test edges $3,4$.

Type C. Smooth irregular wire edge. Feels irregular to touch but does not catch on skin. Similar 
to a rough shear job finished by tumbling. Test edges 6,10 .

Type D. Rough irregular wire edge. Feels jagged to touch. Much rougher than typical manufacturing quality. Test edges 5, 9, 13, 15.

\section{B. Test Tissue}

Because of the similarities between pigskin and human skin as described by McGuire and Moore (1972), pigskin was selected as the test tissue for the first test series. Fresh pigskin having an average thickness of $3.2 \mathrm{~mm}$ was obtained from a local meat supply house and used within 48 hours. It had previously been found that pigskin is most vulnerable to puncture when it has a rigid backing simulating bone. It was thought that this would also be true with regard to vulnerability to laceration, particularly under dynamic conditions where use of the rigid backing would result in higher decelerations and higher impact forces. Therefore, the pigskin specimens were mounted directly over the plywood specimen holder, much like the chamois is mounted in Figure 8, except that a thin plastic sheet was used to prevent absorption of grease by the plywood.

C. Test Method

The pendulum head was weighted so that total pendulum weight was $.56 \mathrm{~kg}$. Since the pendulum center 
of gravity was $42.5 \mathrm{~cm}$ from the pendulum pivot and the edge carrier pivot was $52.5 \mathrm{~cm}$ from the pendulum pivot, a vertical force of $.45 \mathrm{~kg}$ at the carrier pivot could hold the pendulum arm in a horizontal position. This $.45 \mathrm{~kg}$ force was called the "effective weight" of the pendulum. The "effective weights" of children's hands had previously been found to be $.3 \mathrm{~kg}$ and $.6 \mathrm{~kg}$ for 5 and 8 year olds, respectively. Therefore, it was thought that for a given test velocity, the amount of energy available at impact with the pendulum would be less than, and probably only about 75 percent of, that available in the hand of an 8 year old at the same velocity. However, precise measurements of moments of inertia and centers of percussion were not attempted on either the pendulum or the children's hands.

The edge carrier was set to bring the edge into contact with the test tissue at an angle of $15^{\circ}$ to the direction of travel, and to ride over the tissue in the manner shown in Figure 11. One series of tests was run with the carrier spring installed, and one series was run with it removed. (This spring, which produced a force of about $1.5 \mathrm{~kg}$ at full compression, can be seen in the photographs in Figure 11.) Since the carrier complete with edge weighed only .13 kg, the test conditions, 
particularly for tests without the carrier spring, were thought to be far less severe than actual conditions involved in hand-edge impacts at $15^{\circ}$ impact angles.

Before the tests, the pendulum arm was released from various initial angles, and the velocities achieved at the impact point were measured by means of photo diodes. The resulting plot of velocity vs. release angle was used to determine test impact velocities. The higher impact velocities, of course, tended to be accompanied by higher impact forces and decelerations. However, since force and deceleration were not measured, test results are presented in terms of impact velocity. To determine the minimum impact velocity at which each test edge would cut pigskin, about 300 trials were made. For each edge and each test condition (with spring or without spring), the pendulum was released from at least three different initial angles, with three trials at each angle, using a different skin specimen area for each trial.

D. Test Results

Minimum impact velocities at which the 16 test edges would cut rigidly-supported pigskin are shown in the last two columns of Figure 12. The following comparisons can easily be made:

1. "With spring" versus "without spring" conditions. Compare the "with" and "without" columns of results. 
The addition of the carrier spring force reduced required velocity to cut for most edges. This effect was reversed for edges 6 and 16 , the two dullest edges. Overall, the effect of the spring force was small.

2. "0 degree" edge versus "37 degree" edge. Compare edges 2 with $1 ; 4$ with 3 ; and $9,10,11,12$ with 5, 6, 7, 8 . In every case the 37 degree edge required a lower velocity to cut than the 0 degree eage. It was thought that for very thin material there would be little difference between 0 degree and 37 degree edges, but apparently this would require a metal thickness of less than $0.4 \mathrm{~mm}$.

3. $0.4 \mathrm{~mm}$ versus $0.6 \mathrm{~mm}$ versus $1.5 \mathrm{~mm}$ metal thickness. Compare 0 degree edges 8 with 14 with 16. Compare 37 degree edges 9 with 13 with 15 . For the 0 degree edges, thicker material required greater velocity to cut, presumably because of the increased bearing area between edge and tissue. For the 37 degree edges there did not appear to be any significant variation in velocity required to cut with metal thickness.

4. Type A versus Type B versus Type $C$ versus Type D edges. Compare the 0 degree edges 8 with 7 with 6 with 5. Compare the 37 degree edges 12 with 11 with 10 with 9. For both edge angles, the Type C, smooth, 
irregular edges required the highest velocity to cut. The Type D rough, irregular wire edges and Type A smooth, square edges required about half of the velocity of the Type $\mathrm{C}$ edges. The Type $\mathrm{B}$ rough, fine wire edges required the lowest velocity to cut. The Type Bt edges 3 and 4 required about the same velocity to cut as similar Type B edges. As discussed in section II A, measured hand velocities for a five-year old child were 6.4 meters/sec. for a "karate chop" and 2.1 meters/sec. for "quick grab." Maximum hand velocities increase with age. The velocity required to cut pigskin with an edge sheared on a poor, good, or excellent shear and not given further finishing operations was less than .75 meters/sec. for corner contact (37 degree edges), even with low dynamic forces as discussed in Section III C. Human skin is less resistant to puncture than pigskin and is believed to be less resistant to laceration. Therefore, it appears at this time that any toy having exposed, unfinished, sheared sheet steel edges could cut a child's skin under easily obtainable impact conditions. 
IV. CONTINUING ACTIVITIES

A. Improved Test Methods

The pendulum skin test device described in Section II B did not prove to be satisfactory, primarily because interactions between pendulum components and the test tissue were complex and difficult to analyze. Because of this, a different experimental approach is now being used. It's chief features are:

1. A less complex impact test device has been built and is now being used to simulate impact conditions resulting from child-toy interactions.

2. An essentially constant speed test device, utilizing a machine lathe to bring test edges and test tissue into contact under closely controlled conditions, is being developed to investigate the relative effects of pressure and velocity in skin cutting. This device will first be used to cut human skin and various synthetic materials in an attempt to find a material that simulates the reaction of skin to cutting.

3. Arrangements have been made to obtain specimens of human skin for testing in NBS laboratories.

The new test equipment and methods, just now coming into use, will be fully described in future progress reports. 
B. Impact Skin Puncture Test Results (Preliminary)

The impact test device now in use is a drop test device capable of approximating the hand weight and velocity conditions discussed in Section II A. In the course of developing this device, some measurements were made of the puncture resistance of pigskin under impact conditions. The results, though preliminary, are of sufficient importance to present at this time. The test device was used to produce impacts between Moore penetrometer tips and rigidly supported pigskin at angles of 87,45 , and 30 degrees. Three relatively non-hazardous Moore penetrometer tips were used, each point being installed in a circular drop head with about $3.0 \mathrm{~mm}$ of the point protruding from the head. Thickness of the pigskin used was about 2.0mm. The drop head was released from various heights, producing impact velocities of up to 2.4 meters/ sec. (as reported in Section II A, the "quick-grab" hand velocity of an 8 year old child is about 2.5 meters/ sec.). The higher impact velocities, of course, produce higher impact forces, but no force estinates have yet been made. Results of the test drops were as follow: 


\begin{tabular}{l|c|c|c|}
$\begin{array}{c}\text { Impact } \\
\text { Angle, } \\
\text { deg. }\end{array}$ & $\begin{array}{c}\text { Tip } \\
\text { Angle, } \\
\text { deg. }\end{array}$ & $\begin{array}{c}\text { Tip } \\
\text { Radius, } \\
\text { mm }\end{array}$ & $\begin{array}{r}\text { Impact Velocity } \\
\text { Reg'd for Puncture, } \\
\text { meters/sec. }\end{array}$ \\
\hline \multirow{2}{*}{87} & 15 & .80 & 2.4 \\
& 90 & .05 & 2.0 \\
45 & 120 & .05 & 2.4 \\
& 15 & .80 & 1.4 \\
& 90 & .05 & $>2.4$ \\
& 120 & .05 & $>2.4$ \\
& 15 & .80 & 2.0 \\
& 90 & .05 & $>2.4$ \\
& 120 & .05 & $>2.4$ \\
\hline \multirow{4}{*}{30} & & &
\end{tabular}

No attempt at detailed analysis of the preliminary test results will be made in this report. However, one significant aspect of the results is that even the least hazardous Moore tips punctured the pigskin under impact conditions that, it is thought, could easily be achieved by the hand of an 8 year old child. Since it was reported by Moore and McGuire (1972) that pigskin is more resistive to puncture than human skin under low velocity conditions, it is probable that pigskin is also more resistive to puncture under higher velocity conditions. In that case, the test conditions used in these tests would also have resulted in the puncture of human skin. Therefore, even the least hazardous Moore penetrometer tips could be expected to puncture children's skin under rather ordinary impact conditions. This problem is being given further consideration. 
C. Easy-Open Food Containers

A specific problem important to BPS is the presence of sharp edges on the top and within the upper rim of various types of easy-open food cans. It is desirable to evaluate some can designs in the near future, before the general investigation of skin mechanical properties can be completed. Attempts are now being made to develop a simple device that will provide an interim method for evaluating several specific can designs.

D. Basic Skin Properties

PETD is sponsoring a histological investigation of basic skin properties by the University of Virginia School of Medicine. Up to the present, this investigation has not produced any findings affecting the values of skin puncture and laceration resistance described in this series of reports. Results of the investigation will be given in a future NBS report. 


\section{REFERENCES}

1. Damon, A., Stoudt, W. W., and MCFarland, R. A. "The Human Body in Equipment Design." Harvard University Press, Cambridge. Second Printing (1971).

2. Graham, W. H. Data on puncture properties of skin from 21 cadavers. Private correspondence (1972).

3. Hogben, D., Peavy, S. T., and Varner, R. N. "OMNITAB II Magnetic Tape and Documentation Parcel." NBS Tape 1, National Technical Information Service, Springfield, Virginia (1970).

4. Hogben, D., Peavy, S. T., and Varner, R. N. "OMNITAB II User's Reference Manual." National Bureau of Standards Technical Note 552, U.S. Government Printing Office, Washington, D.C. (1971).

5. Holzmann, H., Korting, G. W., Kobert, D., and Vogel, H. G. "Mechanical Properties of Skin in Relation to Age and Sex." Orchiv. Fur Klinische and Experimentelle Dermotologie, 239, 355 (1971).

6. Krogman, W. M., and MCCown, T. "The Manual and Oral Strengths of American White and Negro Children, Age 3-5 Years." Philadelphia Center for Research in Child Growth (1971).

7. McGuire, B. J., and Moore, J. D. "The Skin Puncture Potential of Points Associated with Certain Toys." National Bureau of Standards Report No. 10,839 (1972).

8. Moore, J. D. "A Method for Evaluating and Testing the Sharpness of Points." National Bureau of Standards Report No. 10,673 (1972).

9. Vogel, H. G. Detailed data on tensile properties of skin from 52 cadavers. Private correspondence (1972). 


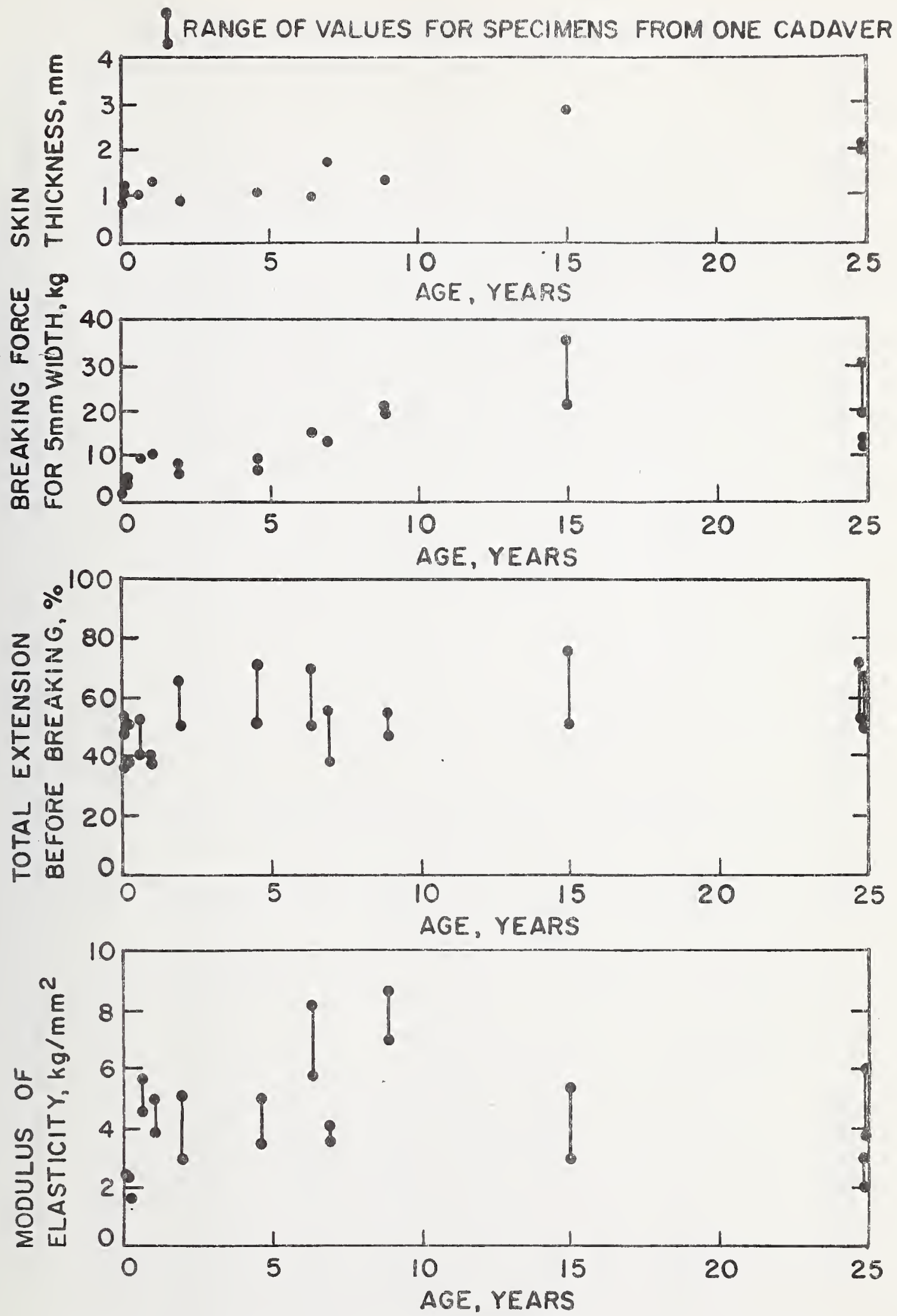

Figure 1. Human Skin Thickness, Breaking Force, Total Extension and Modulus of Elasticity vs. Age, for Skin Over Sternum. From Voge1 (1972). 


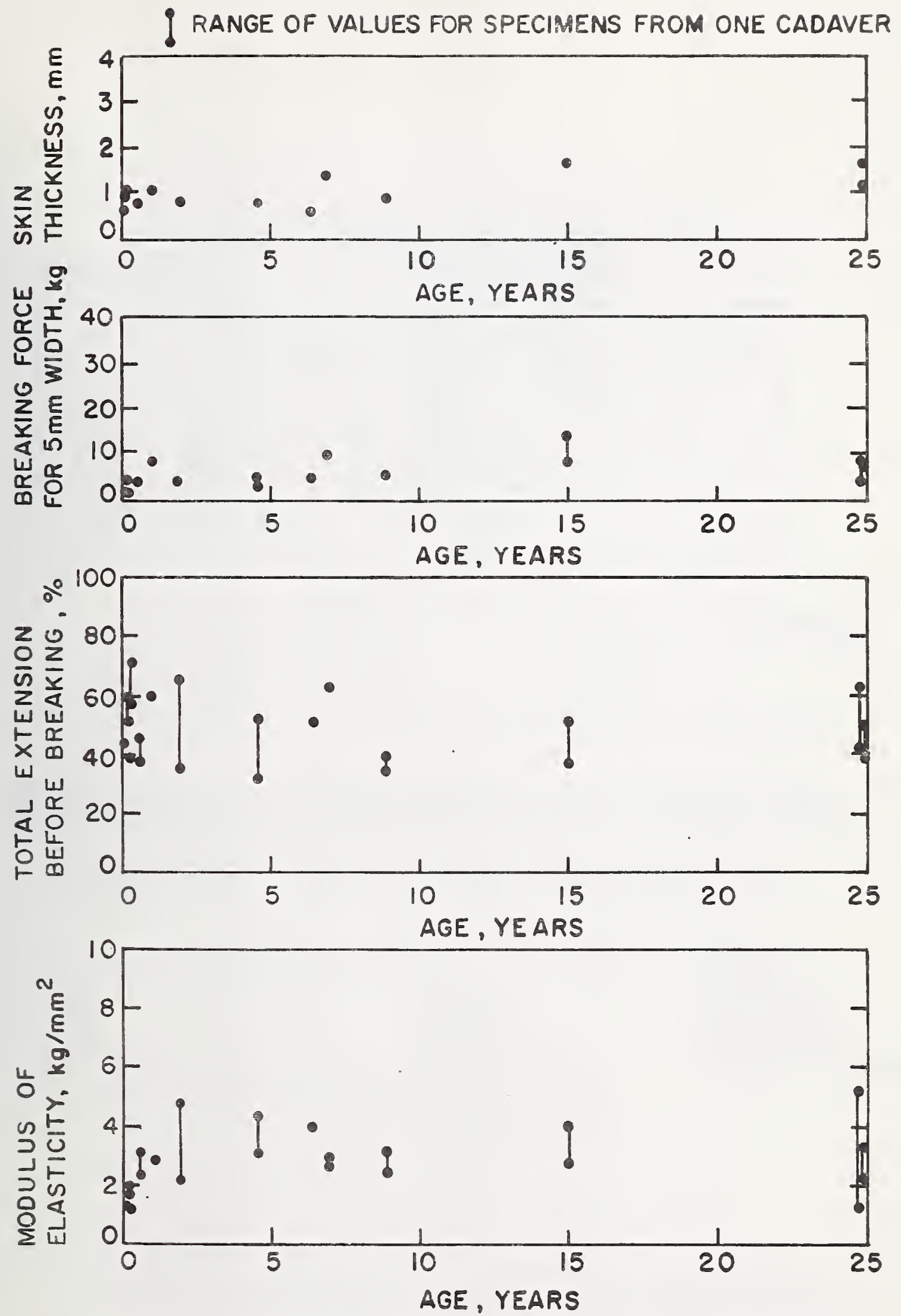

Figure 2. Human Skin Thickness, Breaking Force, Total Extension and Modulus of Elasticity vs. Age, for Skin from Thigh. From Voge1 (1972). 

DIMENSIONS OF MOORE PENETROMETER TIPS

\begin{tabular}{|c|c|c|c|c|c|c|c|c|}
\hline \multicolumn{7}{|c|}{ TIP RADIUS } & \multicolumn{7}{|c|}{ TIP ANGLES DEG. } \\
\hline in. & $\mathrm{mm}$ & 15 & 30 & 45 & 60 & 75 & 90 & 120 \\
\hline .002 & .05 & $x$ & $x$ & $\bigotimes$ & $x$ & $x$ & $x$ & $x$ \\
.004 & .10 & $x$ & $x$ & $x$ & $x$ & $\bigotimes$ & $x$ & \\
.008 & .20 & $x$ & $x$ & $\bigotimes$ & $\varnothing$ & $x$ & $x$ & \\
.012 & .30 & $\bigotimes$ & $x$ & $x$ & $x$ & $x$ & $x$ & \\
.016 & .41 & $x$ & $x$ & $\bigotimes$ & $\bigotimes$ & $x$ & & \\
.024 & .61 & $\bigotimes$ & $x$ & $x$ & $x$ & & & \\
.032 & .81 & $x$ & & & & & & \\
\hline
\end{tabular}
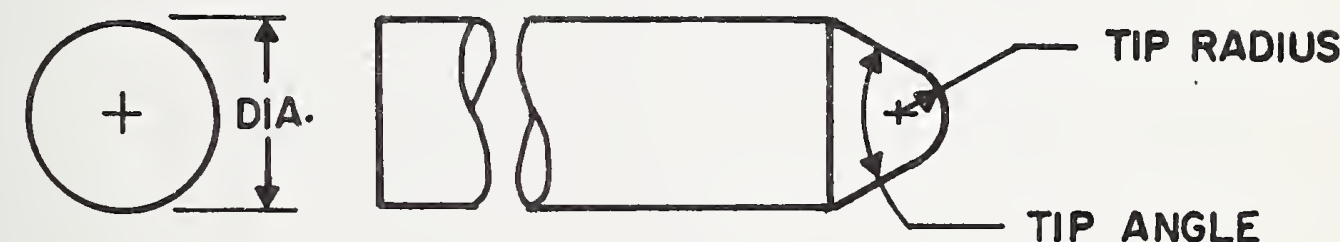

(Q) PENETROMETER TIPS SELECTED FOR USE IN CADAVER TESTS

DIMENSIONS OF MODIFIED GADD PENETROMETER TIP

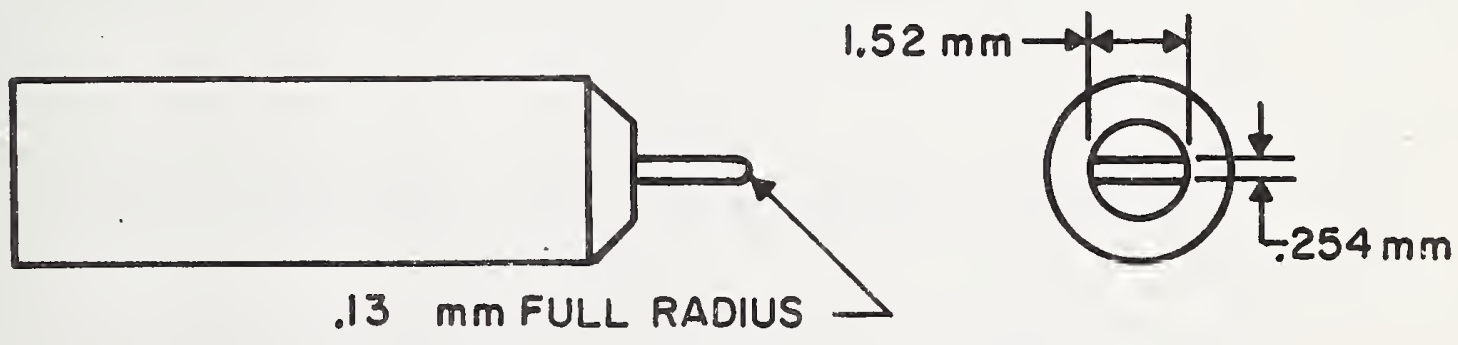

Figure 3. Geometry of Penetrometer Tips Used in this Study. 



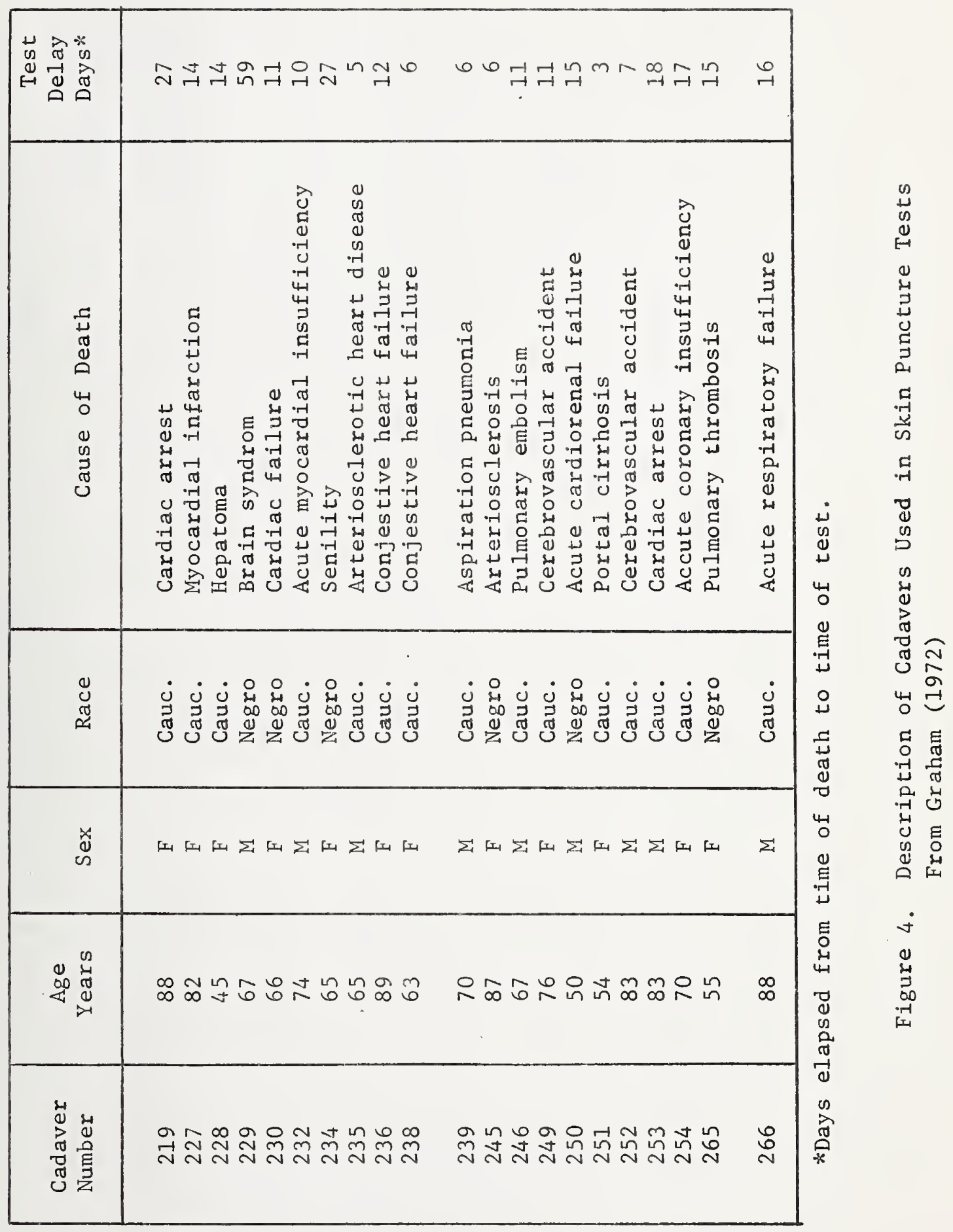





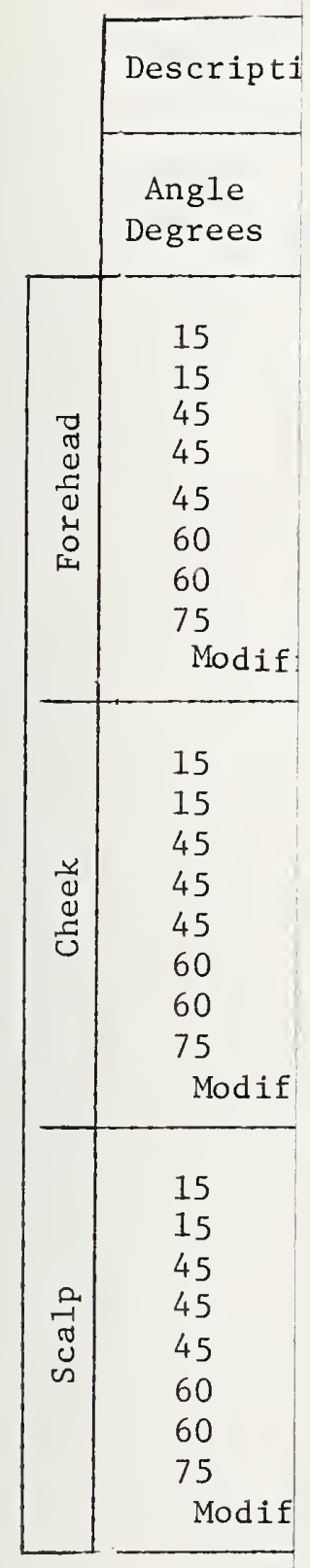

Fïgure 



\begin{tabular}{|c|c|c|c|c|c|c|c|c|c|c|c|c|c|c|c|c|c|c|c|c|c|c|c|c|}
\hline & \multicolumn{2}{|c|}{ Description of Ttp } & \multicolumn{22}{|c|}{ Puncture Force, kg } \\
\hline & $\begin{array}{l}\text { Angle } \\
\text { Degrees }\end{array}$ & $\underset{\mathrm{mm}}{\text { Radius }}$ & 219 & 227 & 228 & 229 & 230 & 232 & 234 & 235 & 236 & 238 & $\begin{array}{c}\text { Cadave } \\
239\end{array}$ & $\begin{array}{l}\text { No. } \\
245\end{array}$ & 246 & 249 & 250 & 251 & 252 & 253 & 254 & 265 & 266 & Mean \\
\hline 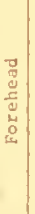 & $\begin{array}{l}15 \\
15 \\
45 \\
45 \\
45 \\
60 \\
60 \\
75 \\
\text { YYodified }\end{array}$ & $\begin{array}{l}0.30 \\
0.61 \\
0.05 \\
0.20 \\
0.41 \\
0.20 \\
0.41 \\
0.10 \\
\text { Gadd }\end{array}$ & $\begin{array}{l}1.8 \\
5.9 \\
1.8 \\
2.3 \\
2.7 \\
3.6 \\
4.5 \\
5.5 \\
2.7\end{array}$ & $\begin{array}{l}2.7 \\
5.9 \\
1.4 \\
2.7 \\
3.6 \\
3.6 \\
5.5 \\
5.9 \\
3.6\end{array}$ & $\begin{array}{r}2.3 \\
10.0 \\
6.5 \\
6.4 \\
7.7 \\
6.4 \\
7.7 \\
7.7 \\
5.5\end{array}$ & $\begin{array}{r}3.2 \\
9.5 \\
2.3 \\
3.6 \\
7.7 \\
9.5 \\
10.5 \\
6.8 \\
5.5\end{array}$ & $\begin{array}{l}3.2 \\
7.3 \\
3.2 \\
4.5 \\
8.2 \\
7.7 \\
8.6 \\
7.3 \\
5.9\end{array}$ & $\begin{array}{r}3.2 \\
9.1 \\
5.9 \\
5.5 \\
8.6 \\
9.5 \\
10.5 \\
11.8 \\
9.1\end{array}$ & $\begin{array}{r}4.5 \\
10.9 \\
5.5 \\
5.0 \\
10.9 \\
7.7 \\
9.1 \\
7.3 \\
6.4\end{array}$ & $\begin{array}{l}2.3 \\
7.3 \\
3.6 \\
3.2 \\
5.9 \\
6.8 \\
9.5 \\
4.1 \\
6.8\end{array}$ & $\begin{array}{l}4.5 \\
4.5 \\
3.6 \\
3.2 \\
5.0 \\
4.5 \\
4.1 \\
5.0 \\
3.2\end{array}$ & $\begin{array}{l}2.7 \\
4.5 \\
3.6 \\
4.1 \\
3.6 \\
3.6 \\
7.3 \\
5.5 \\
3.6\end{array}$ & $\begin{array}{r}4.5 \\
9.1 \\
4.5 \\
6.8 \\
5.5 \\
10.0 \\
12.3 \\
10.0 \\
10.0\end{array}$ & $\begin{array}{r}3.2 \\
10.9 \\
5.5 \\
5.0 \\
8.6 \\
5.0 \\
10.5 \\
9.1 \\
8.2\end{array}$ & $\begin{array}{r}4.5 \\
9.1 \\
5.5 \\
4.1 \\
6.4 \\
5.9 \\
10.0 \\
6.4 \\
7.3\end{array}$ & $\begin{array}{l}3.2 \\
9.5 \\
3.2 \\
3.6 \\
9.1 \\
5.0 \\
6.4 \\
6.4 \\
5.9\end{array}$ & $\begin{array}{r}4.1 \\
10.9 \\
10.0 \\
8.2 \\
12.3 \\
10.0 \\
11.4 \\
13.6 \\
10.9\end{array}$ & $\begin{array}{l}4.1 \\
7.7 \\
3.2 \\
3.6 \\
6.8 \\
6.8 \\
7.3 \\
8.2 \\
5.9\end{array}$ & $\begin{array}{r}3.6 \\
7.7 \\
5.9 \\
6.8 \\
6.4 \\
5.9 \\
6.8 \\
10.9 \\
6.4\end{array}$ & $\begin{array}{l}4.1 \\
6.8 \\
4.5 \\
4.1 \\
6.8 \\
5.5 \\
7.3 \\
4.5 \\
7.3\end{array}$ & $\begin{array}{r}3.6 \\
10.9 \\
4.1 \\
4.1 \\
5.0 \\
4.5 \\
5.9 \\
5.5 \\
6.8\end{array}$ & $\begin{array}{l}5.0 \\
5.5 \\
5.5 \\
5.5 \\
7.3 \\
5.5 \\
8.2 \\
6.8 \\
5.5\end{array}$ & $\begin{array}{l}2.3 \\
6.8 \\
6.4 \\
4.5 \\
7.3 \\
5.5 \\
6.8 \\
6.4 \\
4.5\end{array}$ & $\begin{array}{l}3.5 \\
8.1 \\
4.5 \\
4.6 \\
6.9 \\
6.3 \\
8.1 \\
7.4 \\
6.2\end{array}$ \\
\hline $\begin{array}{l}\frac{.}{d} \\
\stackrel{g}{\mathrm{~s}}\end{array}$ & $\begin{array}{l}15 \\
15 \\
45 \\
45 \\
45 \\
60 \\
60 \\
75 \\
\text { Modified }\end{array}$ & $\begin{array}{l}0.30 \\
0.61 \\
0.05 \\
0.20 \\
0.41 \\
0.20 \\
0.41 \\
0.10 \\
\text { Gadd }\end{array}$ & $\begin{array}{r}4.1 \\
6.8 \\
3.6 \\
5.0 \\
5.9 \\
7.7 \\
8.2 \\
10.0 \\
4.1\end{array}$ & $\begin{array}{l}1.8 \\
6.8 \\
2.3 \\
2.7 \\
5.9 \\
3.6 \\
6.4 \\
4.1 \\
5.5\end{array}$ & $\begin{array}{r}4.1 \\
10.0 \\
4.1 \\
4.5 \\
7.3 \\
6.8 \\
8.2 \\
9.1 \\
5.9\end{array}$ & $\begin{array}{l}3.6 \\
6.8 \\
4.1 \\
5.9 \\
5.9 \\
5.0 \\
7.3 \\
3.6 \\
6.8\end{array}$ & $\begin{array}{l}3.6 \\
7.3 \\
5.5 \\
5.9 \\
7.3 \\
8.6 \\
9.1 \\
9.1 \\
6.8\end{array}$ & $\begin{array}{l}3.6 \\
4.5 \\
6.8 \\
5.5 \\
5.9 \\
6.8 \\
7.7 \\
8.6 \\
4.5\end{array}$ & $\begin{array}{l}3.6 \\
8.2 \\
3.2 \\
5.0 \\
5.5 \\
7.3 \\
8.6 \\
6.8 \\
5.9\end{array}$ & $\begin{array}{l}2.3 \\
5.0 \\
3.6 \\
3.6 \\
6.8 \\
7.3 \\
6.4 \\
6.8 \\
5.5\end{array}$ & $\begin{array}{l}2.3 \\
4.1 \\
2.7 \\
3.2 \\
4.1 \\
4.5 \\
7.7 \\
5.0 \\
4.5\end{array}$ & $\begin{array}{l}3.6 \\
5.0 \\
2.3 \\
5.0 \\
4.5 \\
5.9 \\
7.3 \\
7.7 \\
6.4\end{array}$ & $\begin{array}{r}3.2 \\
10.0 \\
6.4 \\
5.0 \\
7.7 \\
8.2 \\
7.3 \\
9.5 \\
6.8\end{array}$ & $\begin{array}{l}2.3 \\
7.7 \\
2.7 \\
2.7 \\
5.0 \\
5.0 \\
5.9 \\
3.6 \\
4.5\end{array}$ & $\begin{array}{r}2.3 \\
8.6 \\
4.1 \\
4.5 \\
6.8 \\
5.9 \\
10.5 \\
9.1 \\
9.1\end{array}$ & $\begin{array}{l}2.7 \\
5.0 \\
5.5 \\
4.1 \\
5.5 \\
5.5 \\
7.3 \\
9.5 \\
5.5\end{array}$ & $\begin{array}{r}4.1 \\
11.8 \\
4.5 \\
5.0 \\
7.7 \\
6.4 \\
7.3 \\
13.6 \\
6.8\end{array}$ & $\begin{array}{l}3.2 \\
4.5 \\
3.6 \\
4.1 \\
5.5 \\
5.5 \\
5.9 \\
7.3 \\
4.1\end{array}$ & $\begin{array}{l}3.6 \\
7.7 \\
4.1 \\
4.1 \\
5.9 \\
6.4 \\
7.7 \\
6.4 \\
5.5\end{array}$ & $\begin{array}{l}3.2 \\
7.7 \\
4.1 \\
4.1 \\
6.8 \\
3.6 \\
7.7 \\
5.9 \\
6.8\end{array}$ & $\begin{array}{l}2.7 \\
4.5 \\
2.7 \\
3.6 \\
4.1 \\
4.5 \\
4.5 \\
3.6 \\
4.1\end{array}$ & $\begin{array}{r}5.9 \\
10.0 \\
4.5 \\
3.2 \\
6.8 \\
7.7 \\
8.2 \\
6.8 \\
5.5\end{array}$ & $\begin{array}{l}4.1 \\
8.2 \\
3.6 \\
3.2 \\
7.3 \\
7.3 \\
9.1 \\
5.9 \\
4.5\end{array}$ & $\begin{array}{l}3.3 \\
7.2 \\
4.0 \\
4.3 \\
6.1 \\
6.2 \\
7.5 \\
7.2 \\
5.7\end{array}$ \\
\hline 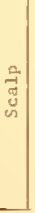 & $\begin{array}{l}15 \\
15 \\
45 \\
45 \\
45 \\
60 \\
60 \\
75 \\
\text { Modified }\end{array}$ & $\begin{array}{l}0.30 \\
0.61 \\
0.05 \\
0.20 \\
0.41 \\
0.20 \\
0.41 \\
0.10 \\
\text { Gadd }\end{array}$ & $\begin{array}{l}2.7 \\
5.9 \\
1.8 \\
3.2 \\
5.5 \\
4.1 \\
8.2 \\
6.8 \\
4.5\end{array}$ & $\begin{array}{l}2.7 \\
6.4 \\
2.3 \\
3.6 \\
5.0 \\
3.6 \\
6.8 \\
5.5 \\
5.0\end{array}$ & $\begin{array}{l}2.3 \\
9.1 \\
3.6 \\
5.5 \\
7.7 \\
5.5 \\
8.2 \\
6.8 \\
7.3\end{array}$ & $\begin{array}{r}3.2 \\
9.5 \\
4.5 \\
6.4 \\
6.8 \\
7.7 \\
10.0 \\
11.8 \\
6.8\end{array}$ & $\begin{array}{r}4.5 \\
8.2 \\
4.1 \\
4.1 \\
7.3 \\
5.5 \\
10.0 \\
6.4 \\
5.5\end{array}$ & $\begin{array}{r}2.3 \\
7.3 \\
5.5 \\
6.4 \\
8.6 \\
10.5 \\
9.1 \\
12.3 \\
7.7\end{array}$ & $\begin{array}{r}5.5 \\
12.3 \\
4.1 \\
7.7 \\
10.5 \\
11.4 \\
12.3 \\
11.8 \\
7.3\end{array}$ & $\begin{array}{r}2.3 \\
6.8 \\
6.8 \\
6.4 \\
5.5 \\
5.5 \\
10.0 \\
6.8 \\
9.1\end{array}$ & $\begin{array}{l}1.4 \\
4.5 \\
2.7 \\
4.1 \\
6.4 \\
5.5 \\
7.3 \\
9.1 \\
4.5\end{array}$ & $\begin{array}{l}2.3 \\
4.5 \\
3.6 \\
3.6 \\
3.6 \\
4.5 \\
5.5 \\
5.0 \\
4.5\end{array}$ & $\begin{array}{r}6.4 \\
12.3 \\
9.1 \\
7.7 \\
12.7 \\
11.8 \\
12.7 \\
13.2 \\
11.4\end{array}$ & $\begin{array}{r}5.0 \\
9.1 \\
5.0 \\
5.5 \\
7.7 \\
6.8 \\
10.9 \\
6.8 \\
9.1\end{array}$ & $\begin{array}{r}3.6 \\
10.0 \\
4.5 \\
4.5 \\
8.6 \\
6.8 \\
11.4 \\
10.0 \\
6.4\end{array}$ & $\begin{array}{l}3.6 \\
5.5 \\
3.6 \\
3.6 \\
5.0 \\
5.5 \\
5.5 \\
5.5 \\
5.5\end{array}$ & $\begin{array}{r}6.4 \\
13.2 \\
10.5 \\
11.4 \\
12.7 \\
11.4 \\
13.6 \\
13.6 \\
13.6+\end{array}$ & $\begin{array}{r}5.0 \\
8.6 \\
4.1 \\
4.1 \\
5.9 \\
4.5 \\
10.0 \\
7.7 \\
7.3\end{array}$ & $\begin{array}{r}5.0 \\
7.7 \\
6.8 \\
5.5 \\
7.3 \\
7.7 \\
11.4 \\
12.3 \\
5.9 \\
\end{array}$ & $\begin{array}{r}5.0 \\
12.7 \\
4.5 \\
4.1 \\
9.1 \\
8.2 \\
10.9 \\
8.6 \\
9.1 \\
\end{array}$ & $\begin{array}{l}4.1 \\
8.6 \\
5.5 \\
4.5 \\
6.4 \\
5.9 \\
6.8 \\
5.5 \\
6.8\end{array}$ & $\begin{array}{r}5.5 \\
10.9 \\
4.5 \\
3.2 \\
8.2 \\
7.7 \\
7.3 \\
6.8 \\
6.8\end{array}$ & $\begin{array}{r}5.0 \\
11.8 \\
5.5 \\
3.6 \\
7.7 \\
7.7 \\
9.1 \\
9.1 \\
4.5\end{array}$ & $\begin{array}{l}4.0 \\
8.8 \\
4.9 \\
5.2 \\
7.5 \\
7.0 \\
9.4 \\
8.6 \\
7.1\end{array}$ \\
\hline
\end{tabular}

+ Force required was slightly above maximuin force gage reading.

Figure 5. Force required to puncture adult human $s k \ln$ with Noore and modffied Gadd Penetrometer tips. For forehead, cheek and scalp. 



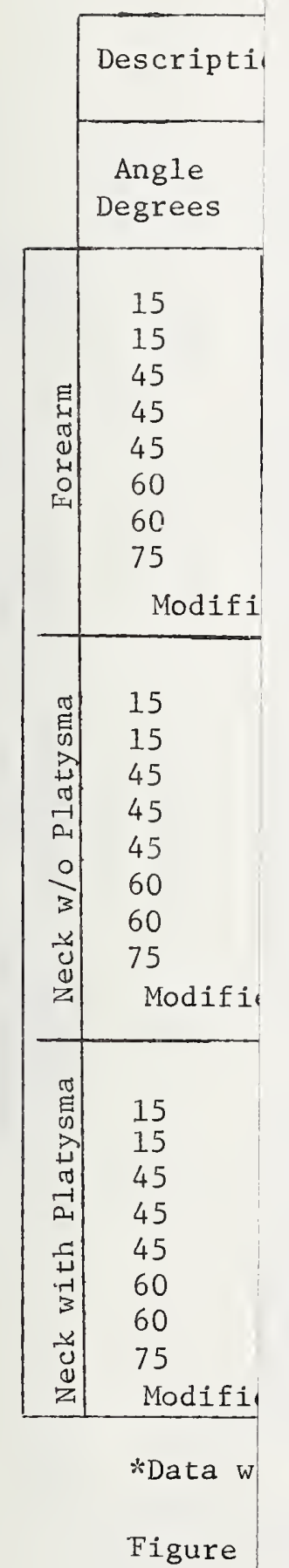





\begin{tabular}{|c|c|c|c|c|c|c|c|c|c|c|c|c|c|c|c|c|c|c|c|c|c|c|c|c|}
\hline \multicolumn{3}{|c|}{ Description of Tip } & \multicolumn{22}{|c|}{ Puncture Force, $\mathrm{kg}$} \\
\hline & $\begin{array}{l}\text { Angle } \\
\text { Degrees }\end{array}$ & $\begin{array}{c}\text { Radius } \\
\text { mat }\end{array}$ & 219 & 227 & 228 & 229 & 230 & 232 & 234 & 235 & 236 & $\begin{array}{l}\text { Cat } \\
238\end{array}$ & $\begin{array}{r}\text { daver } \\
239\end{array}$ & No. & 246 & 249 & 250 & 251 & 252 & 253 & 254 & 265 & 266 & Nean \\
\hline 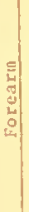 & $\begin{array}{l}15 \\
15 \\
45 \\
45 \\
45 \\
60 \\
60 \\
75 \\
\text { Modified }\end{array}$ & $\begin{array}{l}0.30 \\
0.61 \\
0.05 \\
0.20 \\
0.41 \\
0.20 \\
0.41 \\
0.10 \\
\text { Gadd }\end{array}$ & $\begin{array}{l}3.6 \\
6.4 \\
4.5 \\
3.2 \\
7.3 \\
5.5 \\
7.3 \\
8.6 \\
4.5\end{array}$ & $\begin{array}{l}2.3 \\
5.5 \\
2.3 \\
3.2 \\
3.6 \\
2.7 \\
4.5 \\
4.5 \\
3.6\end{array}$ & $\begin{array}{r}3.6 \\
9.1 \\
5.5 \\
3.6 \\
8.2 \\
10.0 \\
7.3 \\
7.7 \\
5.5\end{array}$ & $\begin{array}{l}4.5 \\
8.6 \\
2.7 \\
3.6 \\
7.3 \\
5.5 \\
7.7 \\
4.5 \\
6.8\end{array}$ & $\begin{array}{l}4.1 \\
9.1 \\
5.0 \\
3.2 \\
6.8 \\
6.4 \\
9.5 \\
5.9 \\
6.8\end{array}$ & $\begin{array}{r}2.7 \\
11.8 \\
5.9 \\
4.1 \\
6.8 \\
5.5 \\
11.4 \\
6.8 \\
6.8\end{array}$ & $\begin{array}{l}3.2 \\
7.7 \\
3.6 \\
3.6 \\
6.4 \\
3.6 \\
3.3 \\
5.9 \\
5.5\end{array}$ & $\begin{array}{r}3.6 \\
10.0 \\
4.5 \\
6.4 \\
6.4 \\
9.1 \\
10.9 \\
8.6 \\
5.0\end{array}$ & $\begin{array}{l}2.7 \\
8.6 \\
2.7 \\
2.7 \\
4.5 \\
4.1 \\
5.0 \\
6.4 \\
1.8\end{array}$ & $\begin{array}{r}2.7 \\
9.1 \\
5.0 \\
5.5 \\
9.1 \\
5.9 \\
10.0 \\
5.5 \\
5.5\end{array}$ & $\begin{array}{r}5.0 \\
11.4 \\
6.8 \\
7.7 \\
9.1 \\
11.4 \\
12.7 \\
13.2 \\
10.0\end{array}$ & $\begin{array}{r}4.5 \\
10.5 \\
3.2 \\
3.2 \\
6.8 \\
5.5 \\
5.0 \\
4.1 \\
6.4\end{array}$ & $\begin{array}{r}5.5 \\
12.7 \\
3.6 \\
3.6 \\
6.8 \\
5.9 \\
10.5 \\
7.3 \\
10.9\end{array}$ & $\begin{array}{r}4.1 \\
9.1 \\
2.7 \\
4.1 \\
8.2 \\
5.5 \\
10.5 \\
10.5 \\
8.2\end{array}$ & $\begin{array}{c}4.5 \\
10.5 \\
5.0 \\
8.6 \\
10.0 \\
11.4 \\
13.2 \\
13.6+ \\
11.8\end{array}$ & $\begin{array}{r}3.2 \\
10.0 \\
3.2 \\
2.7 \\
5.9 \\
4.5 \\
11.4 \\
8.2 \\
6.8\end{array}$ & $\begin{array}{r}4.1 \\
10.0 \\
4.1 \\
6.8 \\
8.6 \\
4.5 \\
8.6 \\
9.5 \\
4.5\end{array}$ & $\begin{array}{r}5.0 \\
10.0 \\
3.6 \\
4.5 \\
9.1 \\
5.0 \\
8.2 \\
7.7 \\
9.1\end{array}$ & $\begin{array}{r}3.6 \\
9.1 \\
4.5 \\
3.6 \\
5.9 \\
5.0 \\
10.0 \\
5.5 \\
5.5\end{array}$ & $\begin{array}{r}4.5 \\
9.5 \\
4.5 \\
3.2 \\
10.0 \\
7.3 \\
4.5 \\
6.4 \\
4.5\end{array}$ & $\begin{array}{l}4.1 \\
9.5 \\
2.7 \\
3.2 \\
9.1 \\
4.5 \\
4.1 \\
6.4 \\
4.1\end{array}$ & $\begin{array}{l}3.9 \\
9.4 \\
4.1 \\
4.3 \\
7.4 \\
6.1 \\
8.6 \\
7.5 \\
6.4\end{array}$ \\
\hline 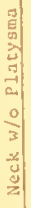 & $\begin{array}{l}15 \\
15 \\
45 \\
45 \\
45 \\
60 \\
60 \\
75 \\
\text { Modifled }\end{array}$ & $\begin{array}{l}0.30 \\
0.61 \\
0.05 \\
0.20 \\
0.41 \\
0.20 \\
0.41 \\
0.10 \\
\text { Gadd }\end{array}$ & $\begin{array}{r}4.5 \\
10.9 \\
1.8 \\
4.1 \\
7.3 \\
8.2 \\
8.6 \\
9.5 \\
3.6\end{array}$ & $\begin{array}{r}4.1 \\
10.5 \\
0.9 \\
3.2 \\
5.9 \\
3.2 \\
7.3 \\
4.5 \\
3.6\end{array}$ & $\begin{array}{r}4.5 \\
12.7 \\
5.5 \\
6.4 \\
11.6 \\
10.5 \\
10.9 \\
9.1 \\
9.5\end{array}$ & $\begin{array}{r}4.5 \\
10.5 \\
1.8 \\
3.2 \\
5.5 \\
6.4 \\
8.6 \\
5.9 \\
4.5\end{array}$ & $\begin{array}{r}4.1 \\
12.7 \\
4.1 \\
3.2 \\
8.2 \\
6.8 \\
10.0 \\
7.7 \\
5.5\end{array}$ & $\begin{array}{r}3.6 \\
11.8 \\
5.5 \\
4.1 \\
8.6 \\
8.6 \\
13.2 \\
9.1 \\
12.3\end{array}$ & $\begin{array}{r}4.5 \\
9.1 \\
3.2 \\
6.8 \\
11.4 \\
8.2 \\
9.5 \\
12.3 \\
5.5\end{array}$ & $\begin{array}{r}4.1 \\
13.2 \\
5.5 \\
5.0 \\
9.1 \\
6.8 \\
11.8 \\
9.1 \\
7.7\end{array}$ & $\begin{array}{r}3.2 \\
11.8 \\
1.8 \\
2.3 \\
6.8 \\
4.5 \\
10.5 \\
8.2 \\
4.5\end{array}$ & $\begin{array}{r}5.5 \\
10.9 \\
5.0 \\
4.5 \\
8.6 \\
7.7 \\
11.8 \\
7.7 \\
6.4\end{array}$ & $\begin{array}{r}3.6 \\
9.1 \\
8.2 \\
4.5 \\
8.6 \\
12.7 \\
4.5 \\
6.8 \\
9.1\end{array}$ & $\begin{array}{r}3.2 \\
13.2 \\
3.6 \\
4.1 \\
10.0 \\
7.3 \\
10.9 \\
3.6 \\
10.0\end{array}$ & $\begin{array}{r}2.7 \\
10.9 \\
2.7 \\
3.6 \\
6.4 \\
4.5 \\
12.7 \\
4.5 \\
7.3\end{array}$ & $\begin{array}{r}3.6 \\
7.7 \\
3.2 \\
4.1 \\
7.7 \\
6.4 \\
9.1 \\
13.6 \\
5.0\end{array}$ & $\begin{array}{r}3.6 \\
13.2 \\
3.6 \\
5.0 \\
11.8 \\
12.3 \\
13.6 \div \\
13.6 \\
13.6\end{array}$ & $\begin{array}{r}4.1 \\
9.5 \\
1.8 \\
4.5 \\
6.8 \\
6.8 \\
13.2 \\
9.5 \\
3.6\end{array}$ & $\begin{array}{r}3.2 \\
9.5 \\
4.5 \\
5.0 \\
6.4 \\
5.9 \\
7.7 \\
12.3 \\
6.4\end{array}$ & $\begin{array}{r}3.6 \\
10.0 \\
4.1 \\
3.2 \\
6.4 \\
4.1 \\
7.3 \\
6.4 \\
7.7\end{array}$ & $\begin{array}{l}3.6 \\
7.7 \\
3.2 \\
3.2 \\
5.9 \\
5.0 \\
8.2 \\
4.5 \\
4.1\end{array}$ & $\begin{array}{r}5.9 \\
10.5 \\
5.9 \\
3.2 \\
10.0 \\
9.5 \\
8.2 \\
10.0 \\
9.1\end{array}$ & $\begin{array}{r}4.5 \\
10.0 \\
5.5 \\
4.1 \\
10.0 \\
9.1 \\
9.5 \\
8.2 \\
9.1\end{array}$ & $\begin{array}{r}4.0 \\
10.7 \\
3.9 \\
4.2 \\
8.3 \\
7.4 \\
9.9 \\
8.4 \\
7.1\end{array}$ \\
\hline 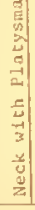 & $\begin{array}{l}15 \\
15 \\
45 \\
45 \\
45 \\
60 \\
60 \\
75 \\
\text { Modified }\end{array}$ & $\begin{array}{l}0.30 \\
0.61 \\
0.05 \\
0.20 \\
0.41 \\
0.20 \\
0.41 \\
0.10 \\
\text { Gadd } \\
\end{array}$ & $\begin{array}{l}\text { * } \\
\text { * } \\
\text { * } \\
\text { * } \\
\text { * } \\
\text { * } \\
\text { * } \\
\text { * }\end{array}$ & $\begin{array}{l}\text { * } \\
\text { * } \\
\text { * } \\
\text { * } \\
\text { * } \\
\text { * } \\
\text { * } \\
\text { * }\end{array}$ & $\begin{array}{r}6.8 \\
12.3 \\
6.4 \\
7.3 \\
11.8 \\
9.5 \\
10.9 \\
10.0 \\
10.5\end{array}$ & $\begin{array}{r}4.5 \\
10.0 \\
2.3 \\
10.0 \\
10.5 \\
6.4 \\
8.6 \\
7.3 \\
7.7 \\
\end{array}$ & $\begin{array}{r}5.5 \\
11.4 \\
4.5 \\
6.4 \\
8.2 \\
8.6 \\
10.5 \\
8.2 \\
8.6 \\
\end{array}$ & $\begin{array}{c}4.1 \\
13.2 \\
3.6 \\
9.5 \\
10.0 \\
11.8 \\
13.6+ \\
9.1 \\
13.6+\end{array}$ & $\begin{array}{c}4.1 \\
13.6+ \\
5.9 \\
6.8 \\
9.1 \\
11.8 \\
11.8 \\
13.2 \\
5.9 \\
\end{array}$ & $\begin{array}{r}5.5 \\
12.7 \\
5.5 \\
6.4 \\
10.5 \\
8.2 \\
13.2 \\
11.8 \\
10.9\end{array}$ & $\begin{array}{l}* \\
* \\
* \\
* \\
* \\
* \\
\star \\
* \\
*\end{array}$ & $\begin{array}{r}8.2 \\
12.7 \\
6.8 \\
5.9 \\
10.5 \\
9.1 \\
12.7 \\
11.4 \\
8.2\end{array}$ & $\begin{array}{r}5.0 \\
12.3 \\
7.7 \\
7.3 \\
10.5 \\
9.1 \\
13.2 \\
11.8 \\
7.3 \\
\end{array}$ & $\begin{array}{r}4.5 \\
13.2 \\
3.2 \\
5.0 \\
8.6 \\
4.5 \\
11.8 \\
4.5 \\
5.0 \\
\end{array}$ & $\begin{array}{r}2.7 \\
11.4 \\
2.7 \\
3.2 \\
6.4 \\
4.5 \\
9.5 \\
5.5 \\
7.7 \\
\end{array}$ & $\begin{array}{r}4.1 \\
10.9 \\
4.5 \\
5.0 \\
9.1 \\
7.7 \\
10.0 \\
12.7 \\
6.8 \\
\end{array}$ & $\begin{array}{r}5.0 \\
13.2 \\
6.4 \\
5.5 \\
11.8 \\
13.6 \\
* \\
* \\
13.2\end{array}$ & $\begin{array}{r}3.6 \\
13.2 \\
2.3 \\
5.5 \\
8.2 \\
5.9 \\
13.6 \\
8.6 \\
6.4 \\
\end{array}$ & $\begin{array}{r}3.6 \\
9.5 \\
6.4 \\
5.9 \\
8.2 \\
7.7 \\
8.2 \\
13.2 \\
5.5\end{array}$ & $\begin{array}{r}4.1 \\
10.0 \\
4.5 \\
4.5 \\
8.2 \\
4.5 \\
9.1 \\
8.2 \\
10.0 \\
\end{array}$ & $\begin{array}{l}3.6 \\
7.7 \\
3.6 \\
4.1 \\
6.8 \\
5.5 \\
7.7 \\
4.5 \\
7.7\end{array}$ & $\begin{array}{r}7.3 \\
12.7 \\
7.7 \\
4.1 \\
11.8 \\
10.5 \\
10.5 \\
11.4 \\
11.4 \\
\end{array}$ & $\begin{array}{r}5.9 \\
11.4 \\
6.8 \\
4.5 \\
12.7 \\
10.5 \\
11.4 \\
10.0 \\
11.4\end{array}$ & $\begin{array}{r}4.9 \\
11.7 \\
5.0 \\
5.9 \\
9.6 \\
8.3 \\
11.9 \\
9.5 \\
8.8 \\
\end{array}$ \\
\hline
\end{tabular}

*Data was not ava1lable

+ Force required was slightly above maximum force gage reading.

Figure 6. Force required to puncture adult human skin with Moore and Modlfled Gadd Penetrometer tips. For forearm, neck without platysma, and neck with platysma. From Graham (1972) 



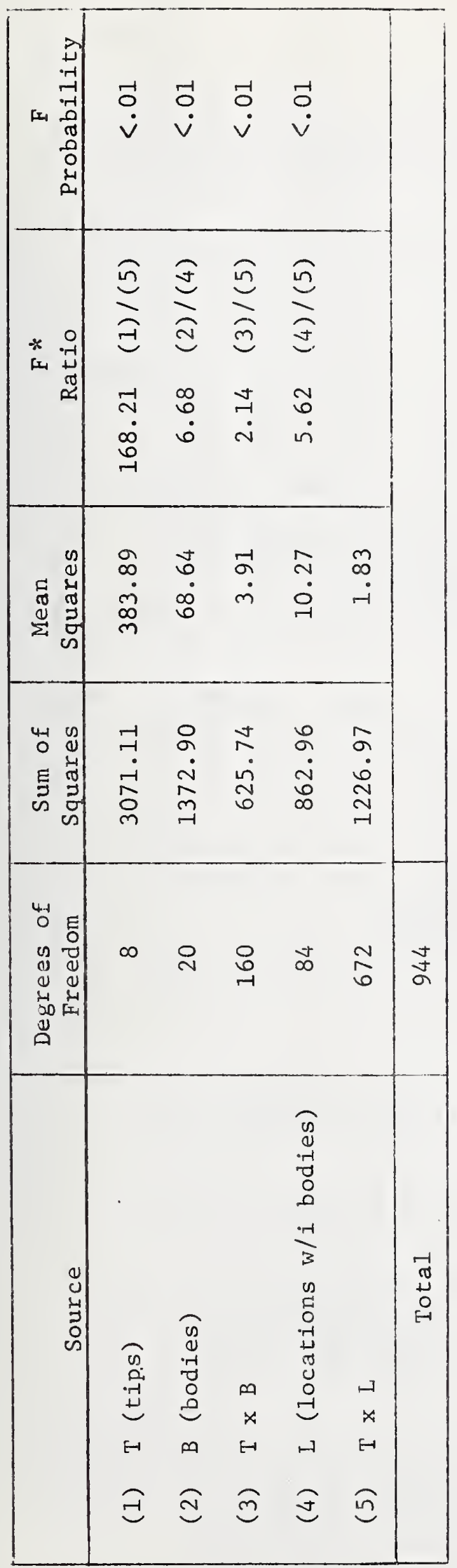

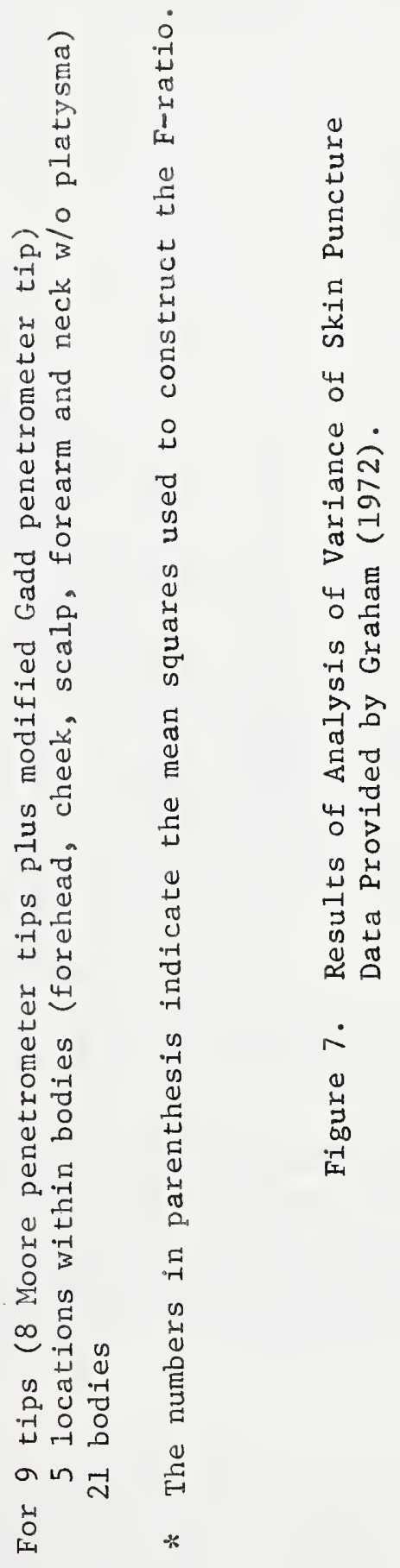





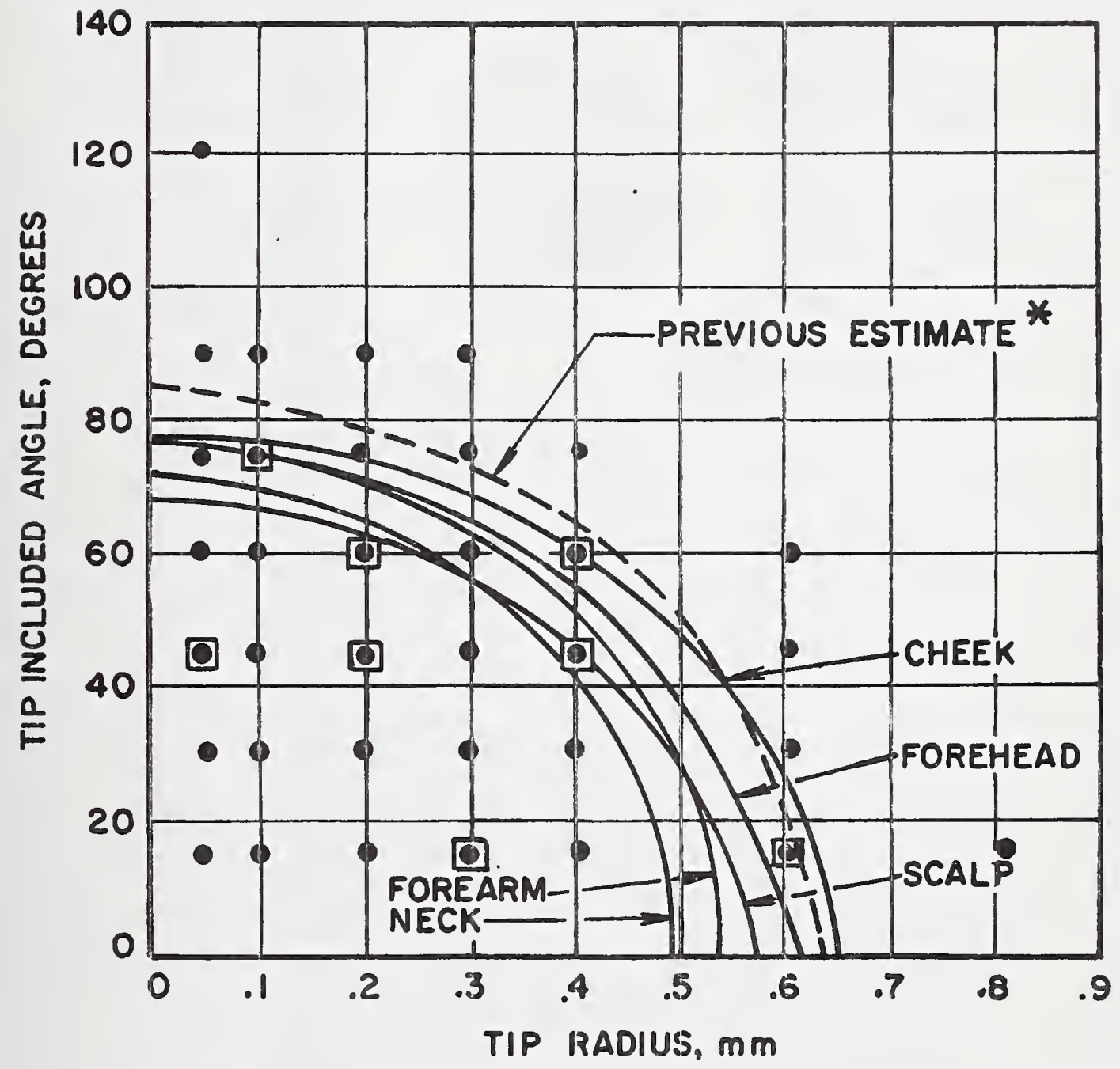

[] COMBINATIONS OF TIP ANGIE AND TIP RADIUS USED IN TESTS ON $2 I$ CADAVERS

* PREVIOUSLY ESTIMATED AVERAGE CURVE FOR 5 LOCATIONS (MCGUIRE AND MOORE 1972)

- COMBINATIONS OF TIP ANGLE AND TIP RADIUS COMPRISING THE COMPLETE SET OF MOORE PENETROMETER TIPS

Figure 8. Combinations of Tip Angle and Tip Radius for Moore Penetrometer Tips That Require a Force of $7.5 \mathrm{~kg}$. to Puncture Adult Human Skin. Data from Forehead, Cheek, Scalp, Forearm, and Neck of 21 Cadavers. 



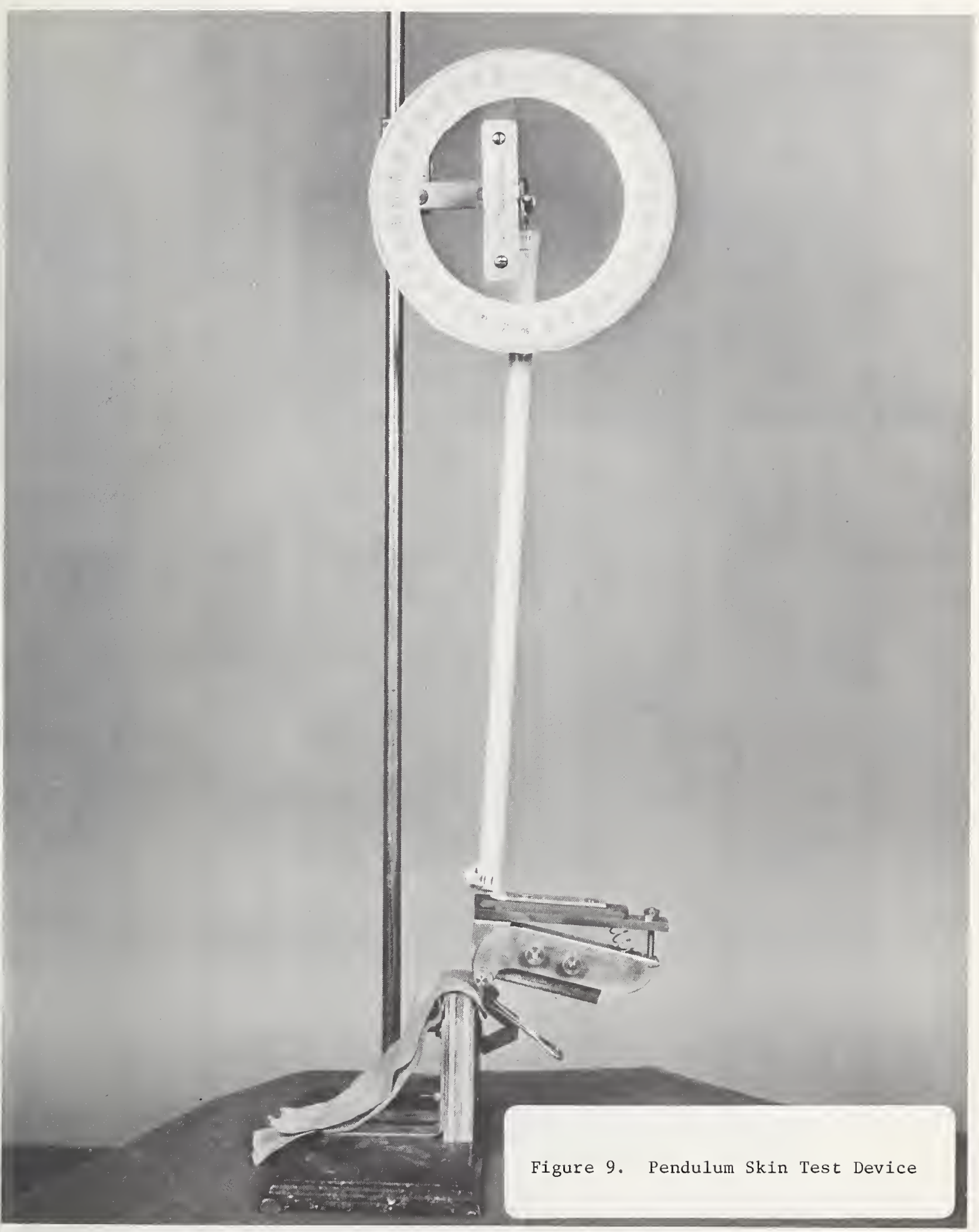




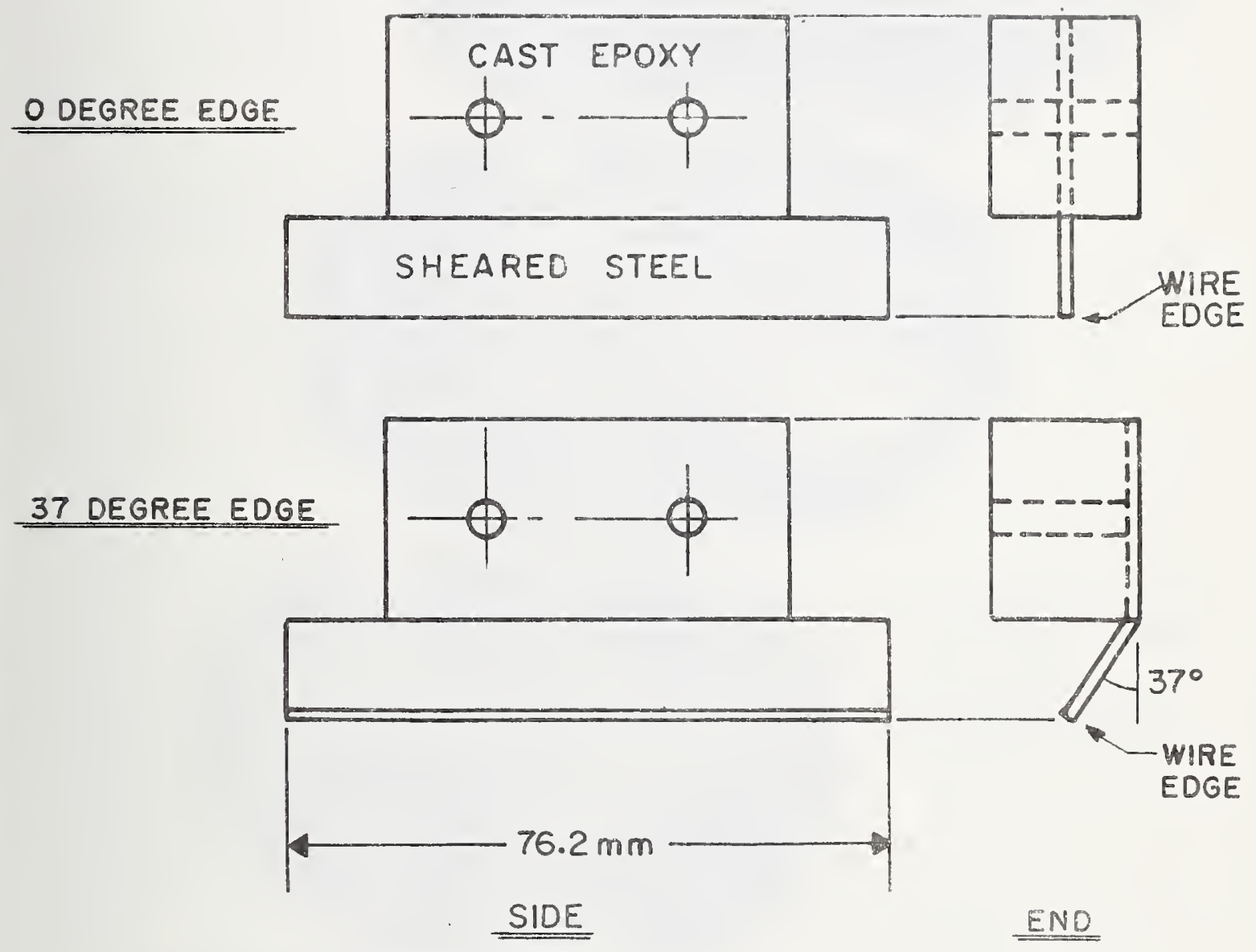

DRAWINGS ARE. APPROXIMATELY - FULL SIZE

Figure 10. Typical Test Edges Used in Tests of Rigidly Supported Pig Skin with Pendulum Test Device 



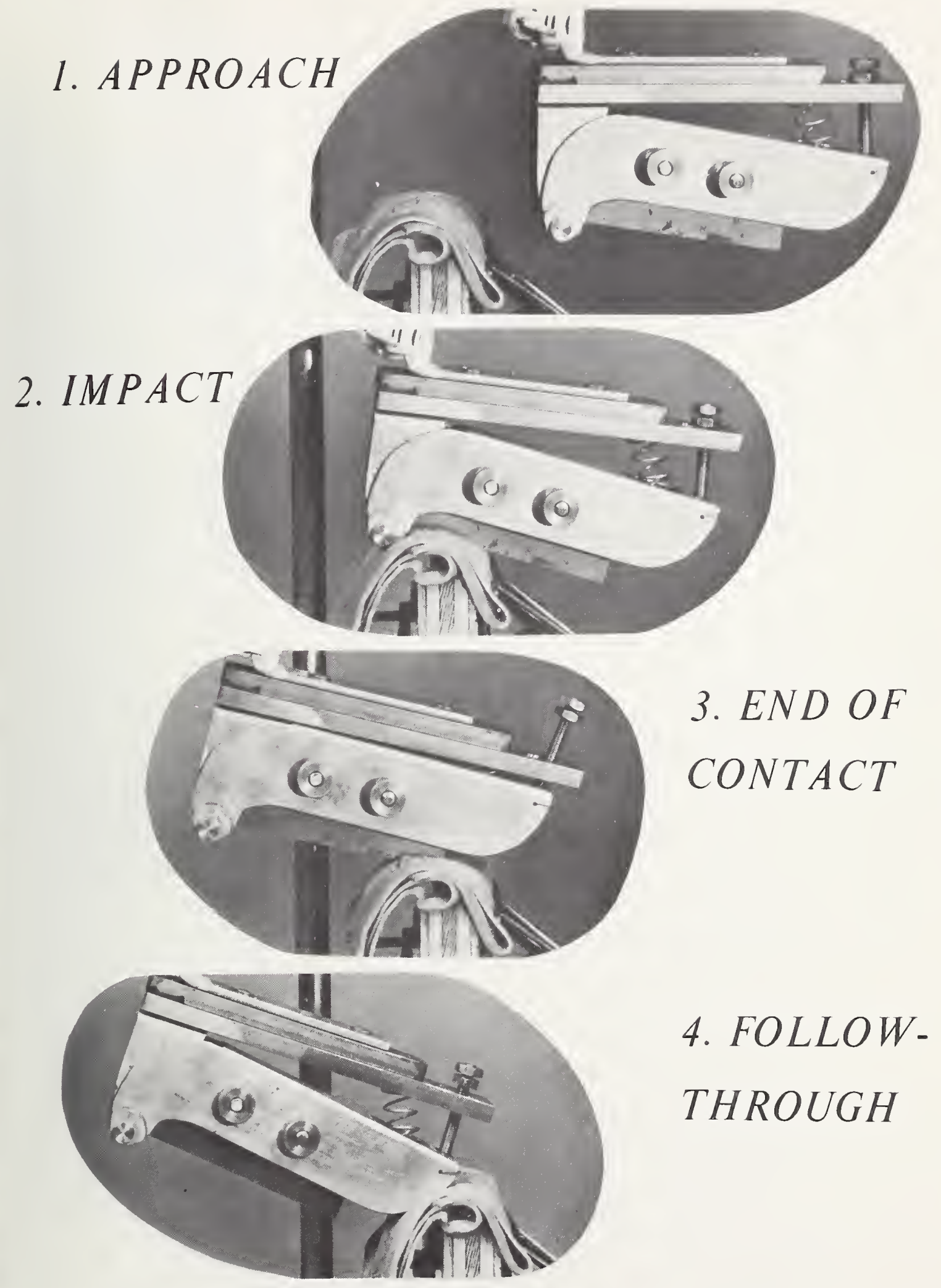

Figure 11. Typical action of edge and carrier of pendulum skin test device during pigskin laceration tests. 



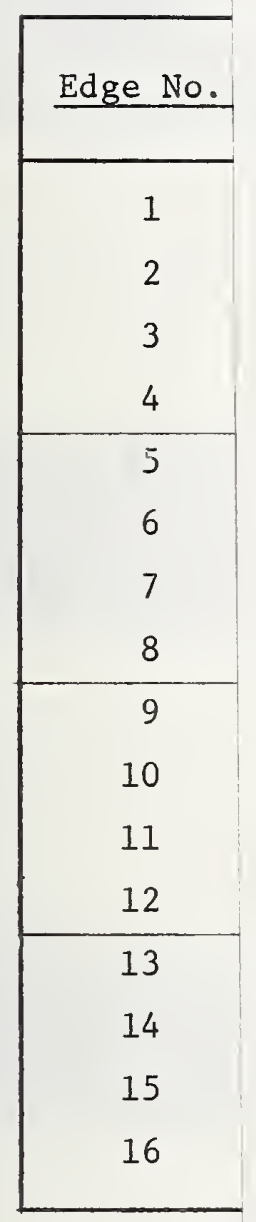

Figure 12 



\begin{tabular}{|c|c|c|c|c|c|c|c|c|}
\hline Edge No. & $\begin{array}{c}\text { Steel } \\
\text { Thickness }\end{array}$ & $\begin{array}{l}\text { Edge } \\
\text { Angle }\end{array}$ & $\begin{array}{c}\text { Shear } \\
\text { Cond1tion }\end{array}$ & $\begin{array}{c}\text { Finish After } \\
\text { Shear }\end{array}$ & $\begin{array}{l}\text { Subjective Description } \\
\text { of Edge as Used }\end{array}$ & $\begin{array}{l}\text { Edge Type } \\
\text { (F1g. 12) }\end{array}$ & \multirow{2}{*}{\multicolumn{2}{|c|}{ P1g Skin Cut Velocity, $\mathrm{m} / \mathrm{sec}$. }} \\
\hline & & deg. & & & & & & \\
\hline 1 & 0.6 & 37 & Good & None & Rough fine wire edge & B & .38 & .38 \\
\hline 2 & 0.6 & 0 & Good & Nione & Rough fine wire edge & B & 1.15 & .94 \\
\hline 3 & 0.6 & 37 & Excellent & None & Rough very fine wire edge & B+ & .38 & .38 \\
\hline 4 & 0.6 & 0 & Excellent & None & Rough very fine wire edge & $\mathrm{B}+$ & .94 & .62 \\
\hline 5 & 0.4 & 0 & Poor & None & Rough irregular wire edge & D & 1.15 & 1.02 \\
\hline 6 & 0.4 & 0 & Poor & 10 strokes & Smooth 1rregular wire edge & c & 2.07 & 2.90 \\
\hline 7 & 0.4 & 0 & Good & None & Rough fine wire edge & B & .51 & .51 \\
\hline 8 & 0.4 & 0 & Good & 20 strokes & Smooth square edge & A & 1.15 & 1.09 \\
\hline 9 & 0.4 & 37 & Poor & None & Rough frregular wire edge & D & .74 & .39 \\
\hline 10 & 0.4 & 37 & Poor & 10 strokes & Smooth 1rregular wire edge & c & 1.45 & .74 \\
\hline 11 & 0.4 & 37 & Good & None & Rough fine wire edge & B & .45 & .39 \\
\hline 12 & 0.4 & 37 & Good & 20 strokes & Swooth squate edge & A & .74 & .67 \\
\hline 13 & 0.6 & 37 & Poor & None & Rough 1rregular wire edge & $\mathrm{D}$ & .58 & .55 \\
\hline 14 & 0.6 & 0 & Good & 20 strokes & Smooth square edge & A & 1.21 & 1.15 \\
\hline 15 & 1.5 & 37 & Poor & None & Rough irregular wire edge & D & .58 & .58 \\
\hline 16 & 1.5 & 0 & Good & 20 strokes & Smooth square edge & A & 2.54 & 2.91 \\
\hline
\end{tabular}

F1gure 12. Characteristics of Sheared Steel Edges Used in Laceration Tests of Rigidly Supported Pig Sk1n. 

Type A. Smooth square edge.

Cut on good shear, fine stone used to remove wire edge.

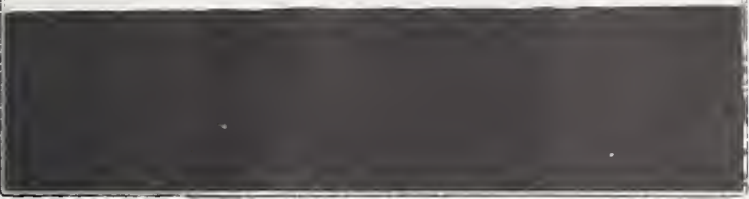

Type B. Fine wire edge. Cut on good shear, no further finishing.

Type C. Smoothed irregular wire edge. Cut on rough shear, fine stone used to remove small irregularities.

Type D. Irregular wire edge. Cut on rough shear, no further finishing.

Figure 13. Types of Sheared Steel Edges Used in Tests of Rigidly Supported Pig Skin. Magnification 50X. 

JRM NBS.114A (1.71)

\begin{tabular}{|c|c|c|}
\hline $\begin{array}{l}\text { U.S. DEPT. OF COMM. } \\
\text { BIBLIOGRAPHIC DATA } \\
\text { SHEET }\end{array}$ & $\begin{array}{l}\text { 1. PUBLICATION OR REPORT NO. } \\
\text { NBSTR } 23=7,23\end{array}$ & $\begin{array}{l}\text { 2. Gov't Accession } \\
\text { No. }\end{array}$ \\
\hline
\end{tabular}

Resistance of Human Skin to Puncture and Iaceration

6. Performing Organization Code

AUTHOR(S)

B. J. McGuire, J.R. Sorre 11s, J. D. Moore

1.PERF ORMING ORGANIZATION NAME AND ADDRESS

NATIONAL BUREAU OF STANDARDS

DEPARTMENT OF COMMERCE

WASHINGTON, D.C. 20234

8. Performing Organization

NBSIR 73-123

10. Project/Task/Work Unit No.

4110410

11. Contract/Grant No.

2. Sponsoring Organization Name and Address

Bureau of Product Safety, Food \& Drug Administration Department of Health, Education, and Welfare

5401 Westbard Avenue

Bethesda, Maryland 20016

i. SUP PLEMENT ARY NOTES

This report is a sequel to NBS Reports No. 10,673 and 10,839

i. ABSTRACT (A 200-word or less factual summary of most significant information. If document includes a significant

bibliography or literature survey, mention it here.)

Information is provided on the following topics:

1. Human skin tensile properties measured on 14 cadavers age 1 day to 25 years. Skin strength increases rapidly during first year of life.

2. Human skin resistance to puncture by conical tips measured on 21 cadavers age 45 to 89 years. Results described by equations of form $y=u+a x_{1}+b x_{2}+c x_{1}^{2}+d x_{2}^{2}$.

3. Hand velocities and weights measured on 5 subjects age 5 to 50 years. Maximum measured velocity during "grabbing" motion was 4.2 meters/sec.

4. Relative laceration ability of selected sheared steel edges measured on pigskin.

5. Preliminary data on resistance of pigskin to puncture by conical tips under impact conditions.

- KEY WORDS (Alphabetical order, separated by semicolons) Adults; Bureau of Product Safety; Children; xperimental Studies; Injury Potential; Lacerations; Mechanical Force; Mechanical roperties; NBS; Punctures; Sampling; Sharp Edges; Simulation; Skin. (TIPS Thesaurus) - AVAILABILITY STATEMENT

UNLIMITED.

X] FOR OFFICIAL DISTRIBUTION. DO NOT RELEASE TO NTIS.

19. SECURITY CLASS (THIS REPORT)

UNCL ASSIF IED

20. SECURITY CLASS

(THIS PAGE) 21. NO. OF PAGES

UNCL ASSIFIED 
FORM NBS.114A: BIBLIOGRAPHIC DATA SHEET (REVERSE SIDE). This Bibliographic Data Sheet is an NBS adaptation of the form prescribed by COSATI guidelines (Appendix 1 . NBS Manual for Scientific and Technical Communications). Please complete with extreme care. This sheet will provide the basis for the literature citation of the publication, and in most cases it will become an integral part of the final'publication itself.

A. Complete item 1 if information is available; otherwise, OTIP will complete later. (See K below.)

B. Ignore toned items $2,6,8$, and 14; these are reserved for possible furure use. Also, ignore item 3.

C. Complete items 4 and 7 .

D. Leave items 5, 21, and 22 blank; OTIP will complete.

E. Items 9, 19, and 20 are preprinted; you need add nothing.

F. Complete items 10,11, and/or 12 when applicable.

G. For item 13, enter "Final" or "Interim" and calendar period covered, as appropriate.

H. For item 15, enter other relevant information. (For example, upon receipt of completed Form NBS-266 from author, OTIP will enter the complete citation for NBS - authored papers published in non-NBS media.)

I. Complete items 16 and 17. Guidance is given in Section 4 and Appendix B of the NBS Manual for Scientific and Technical Communications.

J. For item 18, enter one of the following:

"Unlimited" - for open-literature documents cleared under NBS editorial procedures, or

"For official distribution. Do not release to NTIS" - for limited, restricted, or need-to-know material. (Other availability statements are being developed. If the above are not applicable, contact OTIP for guidance.)

$\mathrm{K}$. In completing item 1, use the brief designators shown in the right-hand column below. Each designator will be followed by the specific publication number for that item. This number will be the same in both the longer and briefer designators for the same document. For example: NBS Technical Note 548 will be equivalent to NBS-TN-548. You would enter NBS-TN-548 in item 1 of Form NBS-114A.

\section{NBS Identificotion}

NBS Technical Nore

NBS Monograph

NBS Handbook

NBS Special Publication

NBS Applied Mathematics Series

NBS National Standard Reference Data Series

NBS Building Science Series

NBS Federal Information Processing Standards Publication

NBS Voluntary Product Standards

NBS Consumer Information Series

NBS Journal of Research Section A

NBS Journal of Research Section B

NBS Journal of Research Section C

NBS Technical News Bulletin
NBS-TN-
NBS-MN-
NBS-HB-
NBS-SP-
NBS-AMS-
NBS-NSRDS-
NBS-BSS
NBS-FIPS-
NBS-PS-
NBS-CIS-
NBS-JRA-
NBS-JRB-
NBS-JRC-
NBS-TNB-

Since each paper in the three-volume NBS Journal of Research is assigned a specific designator, OTIP will add that designator to the appropriate Journal designator shown in the above right-hand column to obtain the entry for item 1 . 



AM 
